\title{
II lessico formale dell'architettura storica: il caso del centro storico di Sambiase
}

\author{
Marco Canciani \\ Giovanna Spadafora \\ Paola Brunori \\ Francesca Laganà
}

\begin{abstract}
II terremoto del 1648 distrusse quasi completamente Sambiase, una frazione di Lamezia Terme, in Calabria, e ne segnò profondamente la storia, determinando l'awio di un lungo e mai definitivamente concluso processo di ricostruzione.

Lo studio del tessuto urbano realizzato attraverso il rilievo fotogrammetrico e 3D, svolto mediante tecniche 'a distanza', insieme all'analisi della documentazione storica, ha permesso di svelare preziose testimonianze del lessico architettonico del barocco calabrese all'interno di un agglomerato multiforme e disordinato. In particolare, lo studio alla scala dell'edificio, condotto sul Palazzo Cerra, ha messo in evidenza le modifiche avvenute durante i secoli e ha permesso di ipotizzare le varie fasi storico-ricostruttive. Questo studio ci consente di riaffermare, ancora una volta, il ruolo del disegno quale strumento di riconoscimento e riappropriazione dei caratteri identitari di un luogo, con la finalità di colmare la distanza nel tempo fra i frammenti di storia urbana e architettonica dispersi in contesti con i quali non hanno più relazione, per rileggerli come parte di una storia continua. Esso riconosce inoltre al disegno la proprietà di superare le distanze fisiche, oggi ulteriormente ampliate dalle restrizioni dovute alla pandemia, grazie alla condivisione e all'uso di metodologie che si basano sulle tecnologie digitali.
\end{abstract}

Parole chiave

Sambiase, rilievo 3D, Palazzo Cerra, Barocco calabrese.

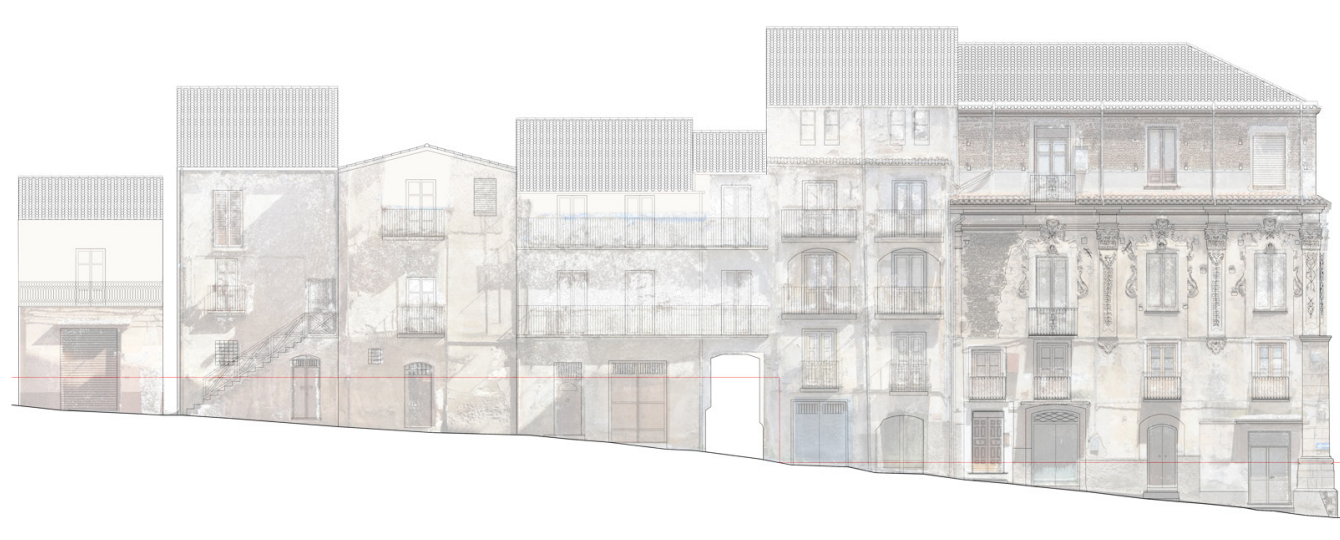




\section{Introduzione}

Nonostante in Italia, il dibattito sulla salvaguardia dei centri storici e sulla necessità del riconoscimento e della tutela dei caratteri identitari dei territori e del costruito, abbia preso avvio fin dalla fine dell'Ottocento [I], ragioni economiche e politiche, unite all'urgenza di dare risposta a problemi contingenti, hanno determinato profonde differenze nei modi e nei tempi degli interventi sui singoli contesti. La Calabria, in particolare, ha visto intensificarsi solo a partire dalla fine degli anni Novanta del Novecento azioni specifiche rivolte al finanziamento di progetti per la riqualificazione e la valorizzazione dei centri storici, anche in chiave di potenziamento dell'offerta turistica e culturale. Occorre tuttavia sottolineare che proprio le ragioni storico-politiche, economiche e sociali, ma anche la fragilità stessa del territorio - che ha visto numerosi terremoti, da quello del I 108 all'ultimo del 1908, distruggere interi centri abitati - hanno fatto sì che il patrimonio architettonico calabrese appaia frammentato in singoli pregevoli episodi ma a volte quasi invisibili all'interno di contesti con i quali non hanno più relazione. Un territorio, dunque, che si è dovuto confrontare più volte con il vuoto lasciato dalle perdite umane e da quelle della propria storia materiale, e poi con i fenomeni delle migrazioni, degli abbandoni e dei ritorni che hanno pesantemente condizionato gli interventi alla scala dell'edificato. In questo contesto, lo studio sul centro storico di Sambiase (uno dei tre Comuni insieme a Nicastro e Sant'Eufemia divenuti dal 1968 circoscrizioni della città di Lamezia Terme [2]) si pone come un ulteriore tassello nell'ambito della ricerca sui centri storici minori della Calabria, ma non solo, da tempo in atto nel Dipartimento di Architettura [3].

Fig. I. Centro storico di Sambiase: rilievo fotogrammetrico da Google Earth, vista assonometrica del modello 3D (elaborazione M. Canciani).

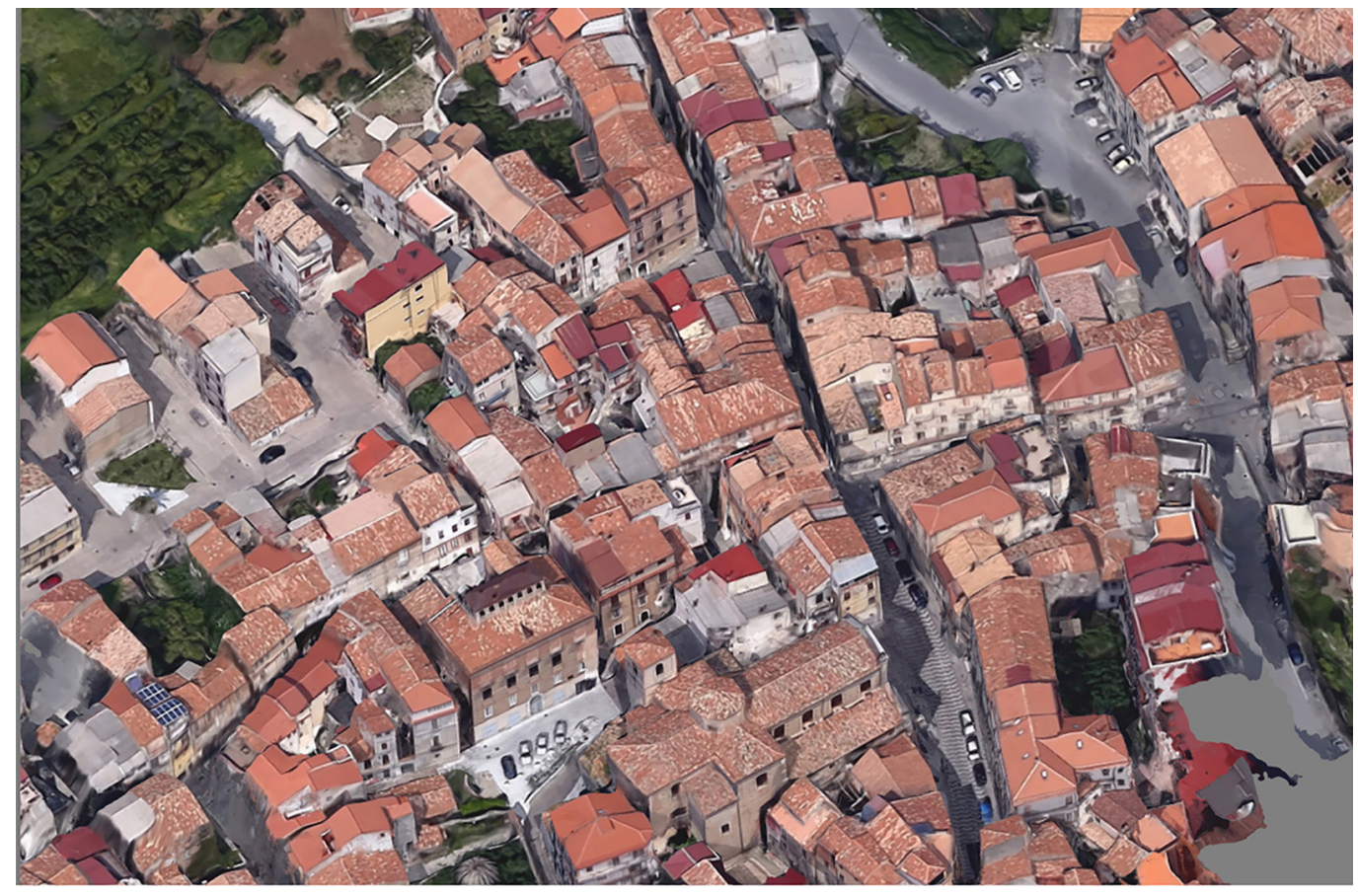

\section{II metodo d'indagine}

La metodologia adottata si basa sulla consolidata integrazione tra ricerca storica e rilievo secondo tre fasi: nella prima, resa difficile dalla lacunosa documentazione disponibile [4], la cartografia acquisita è stata integrata con una disamina puntuale delle fonti bibliografiche e iconografiche. 
La seconda ha riguardato il rilievo 3D del tessuto urbano e degli edifici selezionati come caso di studio. Per il lavoro alla scala urbana, l'impossibilità di ritornare sul posto per completare i rilievi, determinata dalle direttive sanitarie dovute alla pandemia, ha comportato la messa in atto di una procedura che sfrutta le tecnologie a disposizione per colmare le distanze fisiche: sono state utilizzate le immagini acquisite dall'applicazione Google Earth [Canciani, Fioravanti 2020, pp. 34I-355, Chen, Clark 20 I6], per costruire un modello fotogrammetrico georiferito, con un grado di definizione compatibile a una scala l:500 (fig. I). Sia il rilievo alla scala urbana sia quello alla scala degli edifici sono stati elaborati attraverso i principi consueti, basati sulle procedure della fotogrammetria speditiva della SFM (Structure from Motion) [Kraus 2007; Remondino, El-Hakim 2006], e l'utilizzo del programma di fotogrammetria speditiva Metashape.

Nella terza fase, tutti i dati acquisiti attraverso le varie procedure di rilevamento, comprese quelle che è stato possibile condurre direttamente sul posto, sono stati integrati con quelli ricavati dalla documentazione storica, col duplice risultato di ottenere una planimetria georiferita delle coperture (fig. 2), utile alla comprensione delle tipologie edilizie che caratterizzano il tessuto urbano storico di Sambiase e alcuni disegni di dettaglio delle facciate. Questi ultimi, corredati dalle sezioni, sono risultati indispensabili per la comprensione del lessico formale e architettonico che caratterizza gli edifici storici di Sambiase, e in particolare di Palazzo Cerra.

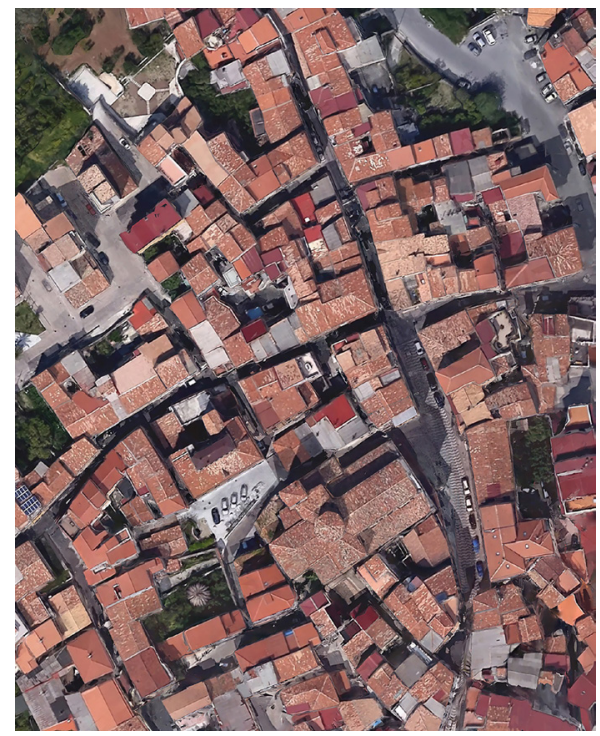

\section{Il tessuto urbano di Sambiase oggi}

II terremoto del 1648 ha rappresentato per la città di Sambiase non solo il momento di una completa distruzione del centro storico, ma anche l'avvio di una lunga fase di ricostruzione di tutto il tessuto edilizio, a prima vista mai definitivamente conclusa [Guidoboni p. 4I6]. Sambiase nel 1948, 300 anni dopo il sisma, appariva "riedificato, ma purtroppo senza alcun criterio igienico ed estetico, vie anguste, piazzette microscopiche, lunghe file di case rustiche...." [Borrello 1948, pp. 252, 253] (fig. 3).

Da quella data, passati più di 70 anni, l'immagine che si percepisce oggi è di un centro storico in cui gli elementi storicizzati sono nascosti da quelli incongrui e moderni, dove gli edifici 'finiti' si contano sulla punta delle dita, in uno "stato di incompiutezza e di semi abbandono" [Proto, Cicione 2005, p. 507], che rappresenta una caratteristica peculiare dei centri storici calabresi, quel "non compiuto architettonico che costituisce un lessico, se pur contraddittorio, del verace genius loci lametino" [Proto, Cicione 2005, p. 503]. 
Fig. 3. Cartoline degli anni ' 40 con alcuni scorci del centro storico di Sambiase.
In questa condizione di difficile lettura, l'osservazione attenta e il rilievo consentono di individuare quegli elementi che rappresentano i caratteri identitari di un luogo, riferiti alle fasi storico formative, alla struttura insediativa, al tessuto edilizio e ai caratteri del costruito [5]: Le raffinate opere in ferro battuto, le plastiche cornici modanate delle finestre, i portoni a bugne, in apparente contrasto con le facciate incompiute in muratura a vista, costituiscono delle efficaci espressioni di un lessico formale tipico del Barocco calabrese [Panarello 2009, pp. I | 2- |24]. A questi elementi così curati non corrisponde una altrettanta attenzione alle tecniche costruttive volte alla protezione dal rischio sismico: pochi i presidi adottati tra i quali le catene, realizzate solo in epoca più recente, i muri a scarpa sugli edifici più alti, i corpi scala esterni a fare da contrafforti, pochi, ancora, gli edifici costruiti con tecniche costruttive adeguate (altezza ridotta e spessori murari notevoli, ai livelli inferiori), che, in parte, ritroviamo nelle Istruzioni reali della Normativa borbonica, cosiddetta Pignatelli, del 1783 [Guidoboni p. 436].

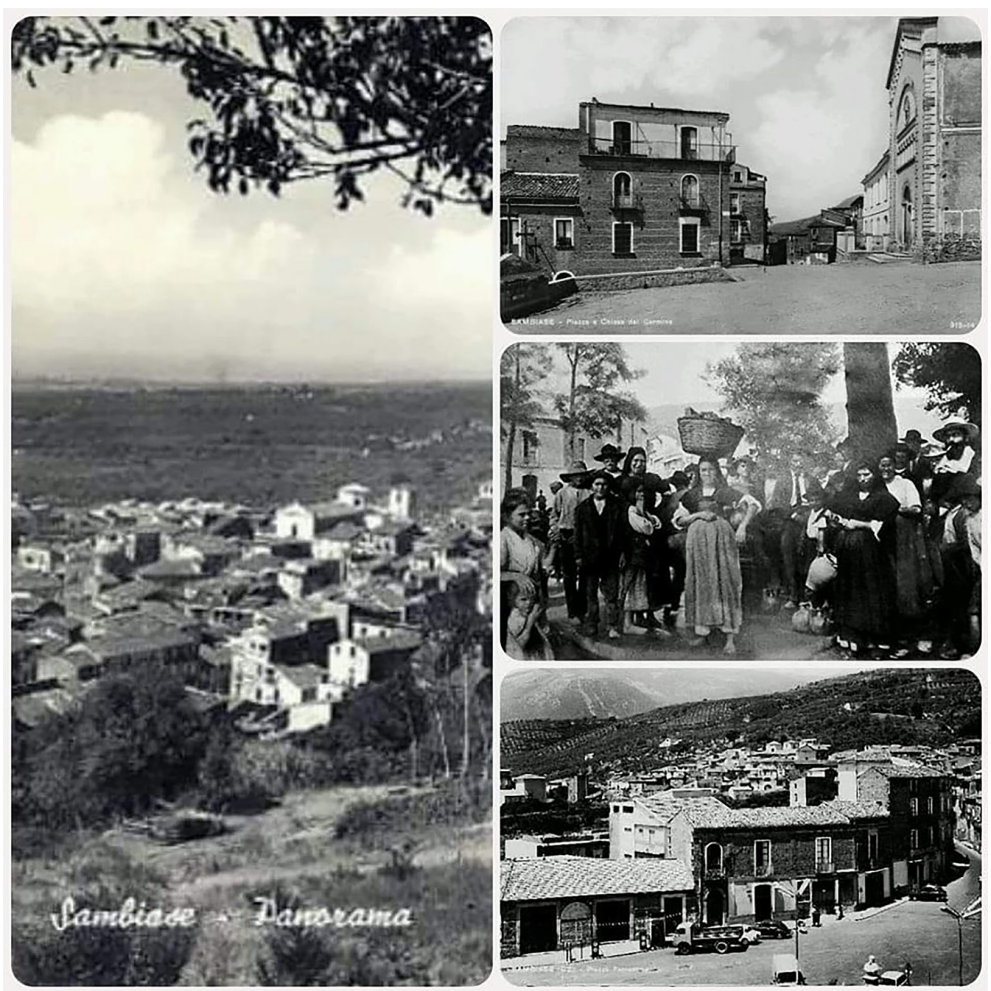

Nell'elaborazione della planimetria (fig. 4), sono evidenziati i diversi edifici, che, depurati da aggiunte, superfetazioni e ampliamenti, costituiscono i tipi edilizi risalenti alle prime fasi successive al terremoto: il basso, un'unità abitativa di un livello, che rappresenta la trasposizione intramoenia della casa rurale [Proto, Cicione 2005, p. 498]; il vignano, che vede l'inserimento di un vano superiore e di una scala esterna; la palazziata, di proprietà aristocratica e organizzata su tre o quattro livelli, con alcuni elementi decorativi di pregio sulle facciate; il palazzo nobiliare, come Palazzo Cerra o Palazzo Nicotera, caratterizzati da una facciata decorata e da un cortile interno, che, in una fase successiva, si modifica in uno spazio interno condiviso, prendendo il nome di vaglio (figg. 5, 6).

II tessuto viario del centro storico da quel momento subisce una trasformazione evidente: dalla fitta rete di vicoli chiusi dai due fronti compatti, con pochi slarghi solo in corrispondenza delle chiese e dei palazzi, a una rete che si dilata nei numerosi vagli, determinando delle pause e delle aperture visuali nel percorso cittadino. 


\section{Ipotesi delle fasi di espansione dell'abitato di Sambiase}

La bibliografia consultata [D'Avino I848, Bonacci 1988; 1989a; I989b; 1989c; Borrello 1948] colloca al X secolo il primo insediamento di Sambiase, intorno al monastero basiliano di San Biagio, quando gli edifici a carattere prettamente rurale iniziarono a insediarsi nei pressi del monastero, assumendo, però, un lessico formale, peculiare dell'architettura cittadina [Proto, Cicione, 2005, p. 498]. Tuttavia, se molta attenzione è stata dedicata alla storia di Chiese e Conventi, pochissimi sono i cenni alle emergenze architettoniche e assenti gli studi sul tessuto urbano. A questo proposito, nella prima fase di studio, la consultazione dell'Archivio di Stato di Catanzaro e dell'Archivio Comunale di Lamezia Terme ha portato al reperimento del Catasto Onciario del I783, del Catasto del I95 I e di una serie di documenti notarili, utili nella formulazione delle ipotesi sulle fasi di espansione dell'abitato. Questo lavoro è stato propedeutico alla successiva analisi del caso di studio.

Fig. 4. Planimetria in cui sono evidenziati tipi edilizi principali: in rosso gli edifici religiosi in giallo i 'bassi', in arancione i 'vignani', in verde le 'palazzlate' e in blu i 'palazzi nobiliari; in marrone sono evidenziati i 'vagli' (elaborazione grafica F. Laganà).

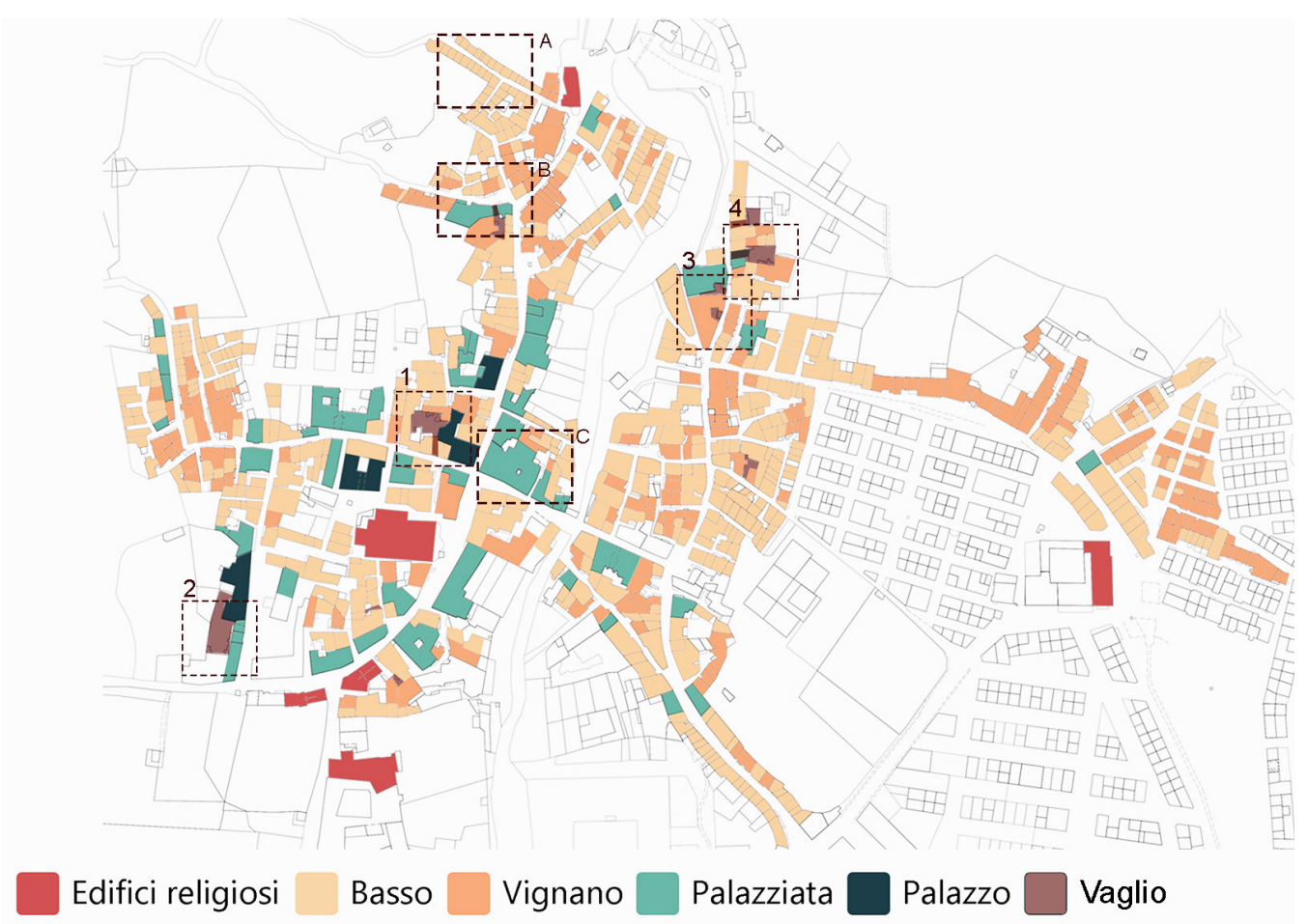

\section{II palazzo Cerra}

Tra i palazzi nobiliari studiati, Palazzo Cerra, già Palazzo Fiore, è certamente uno tra i più interessanti; quel che resta dei dettagli decorativi a stucco delle facciate rappresenta ancora oggi la testimonianza del lessico architettonico del barocco calabrese (fig. 7). Realizzato tra il 1760 e il I780, alla fine dell'Ottocento divenne di proprietà della famiglia Mazzei-Cerra e, all'inizio del Novecento, venne suddiviso in più unità abitative, condividendo con altri palazzi nobiliari un destino legato al mutare delle condizioni economiche e sociali.

La ricostruzione della originaria estensione planimetrica di Palazzo Cerra è scaturita dall'analisi delle evidenze ancora superstiti e dal confronto con Palazzo Nicotera, con il quale presenta diverse analogie. L'assetto attuale, infatti, potrebbe essere il risultato di almeno due fasi di trasformazione dell'edificio originario, al quale si accedeva attraverso un passaggio coperto che immetteva in un cortile. Su questo spazio aperto, ma di esclusiva pertinenza del 
Fig. 5. Abaco dei principali tipi edilizi, evidenziati con una lettera e un riquadro nella planimetria della fig. 04: il basso (A), il'virnano' (B) e la 'palazziata' (C) con indicazione della destinazione d'uso. II verde definisce una zona polifunzionale, il rosso zona giorno, il giallo deposito e blu zona notte (elaborazione grafica F. Laganà).

Fig. 6. Abaco di alcun vagli, denominati atri nella toponomastica, evidenzia con un numero e un riquadro nella planimetria della fig. 4: I. Atrio |

Cavour; 2. Atrio Giuseppe Verdi; 3. Atrio I Ferruccio; 4. Atrio III Ferruccio

(elaborazione grafica F Laganà).

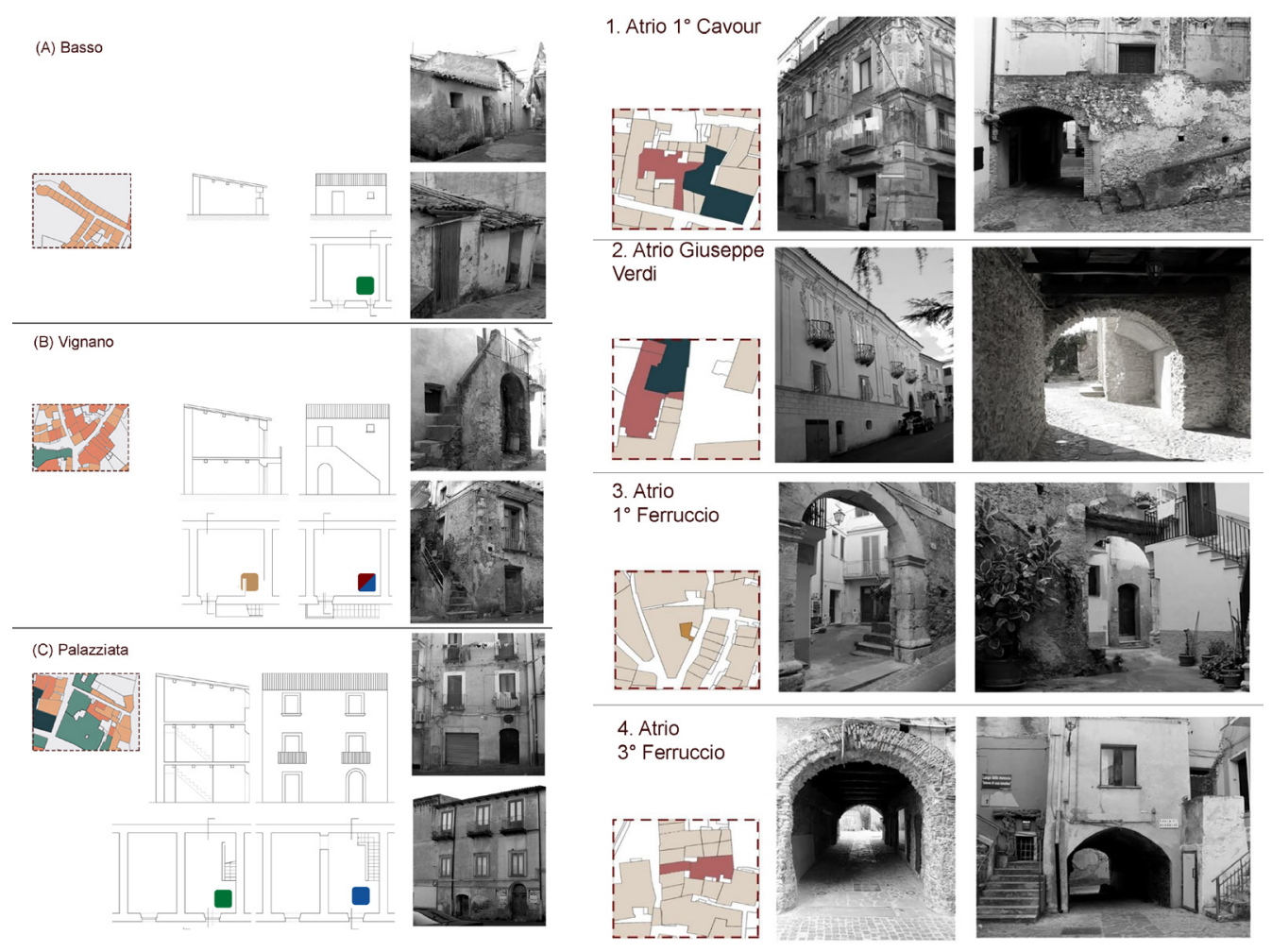

palazzo, si affacciavano gli ambienti di servizio e lo scalone/loggia di accesso al primo piano dell'abitazione, del quale rimangono tracce della preziosa decorazione in stucco.

Probabilmente nella seconda metà dell'Ottocento, si ebbe un pesante rimaneggiamento di una porzione di edificio, e il disegno della facciata perse la sua unitarietà. Ma l'intervento che decisamente corrompe l'immagine originaria del palazzo è la sopraelevazione realizzata nella metà del Novecento.
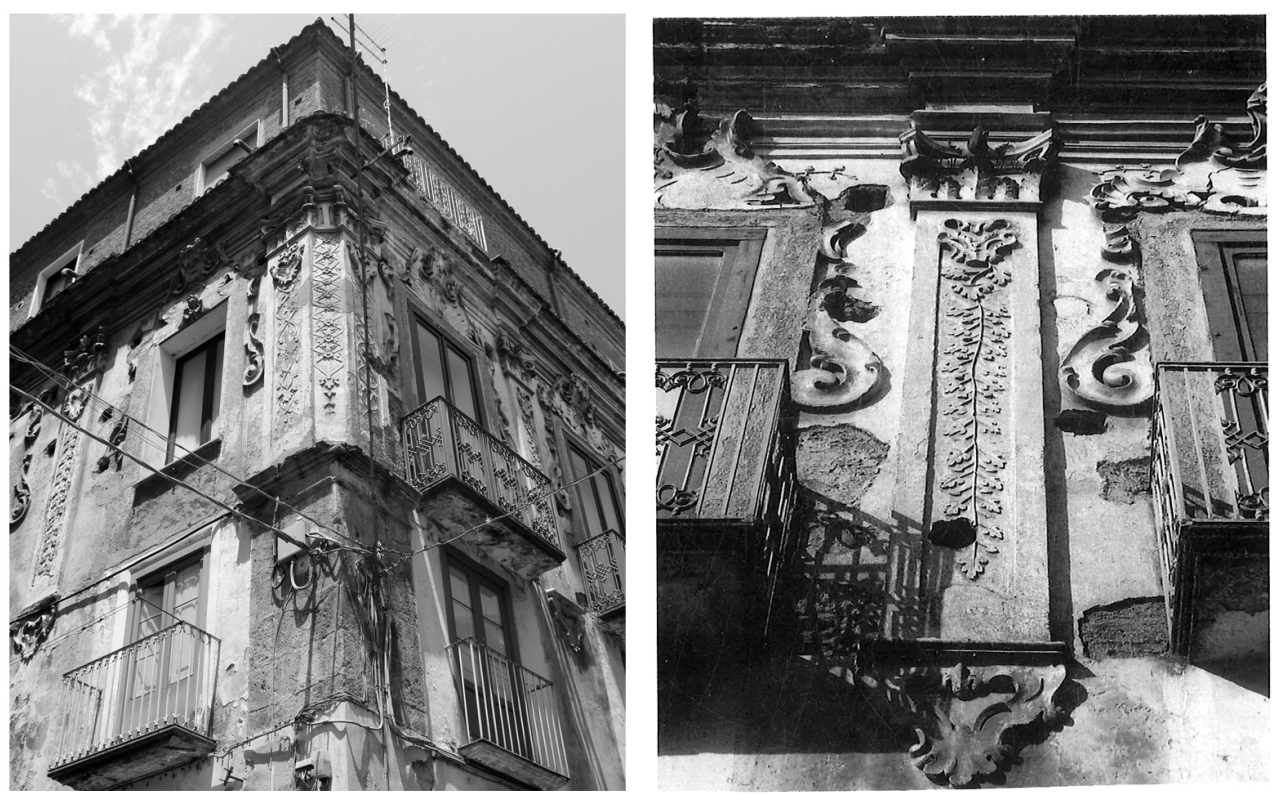
Fig. 8. Palazzo Cerra:

rilievo dei prospetti su

via Cavour e via Porchio

(elaborazione grafica F.
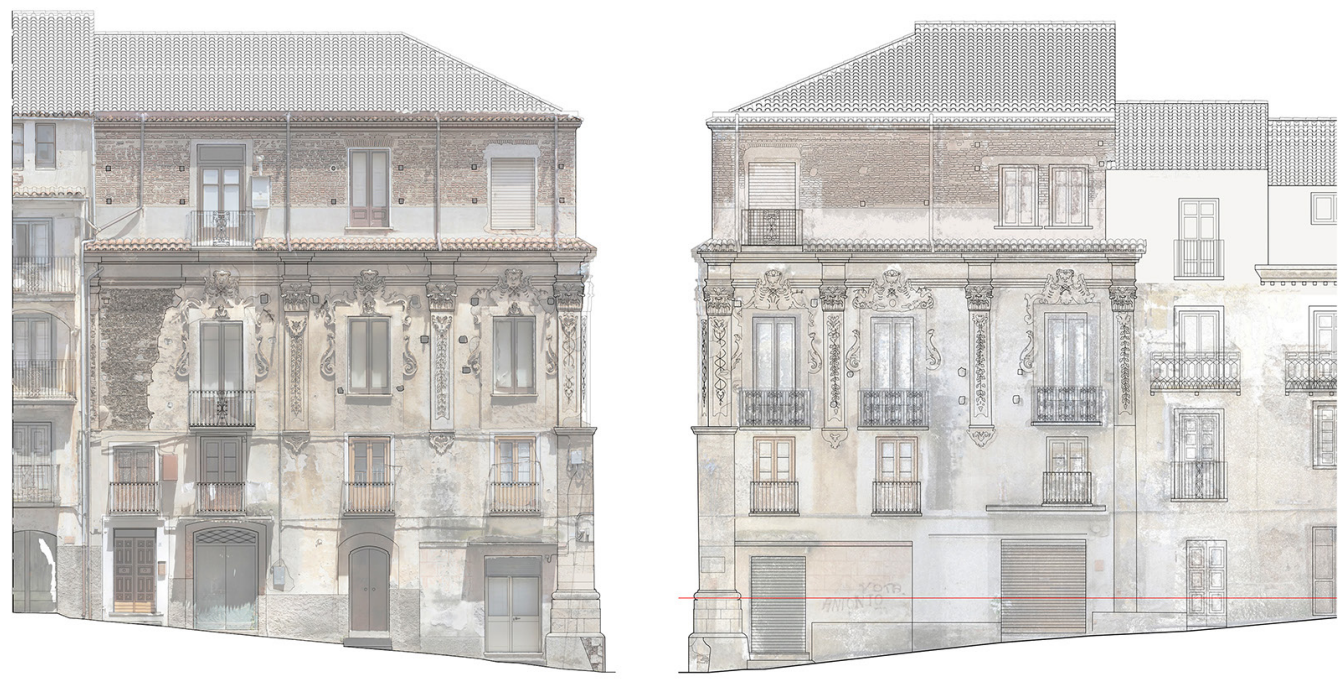

Fig. 9. Palazzo Cerra:

analisi dei materiali de

prospetto su via Cavour

(elaborazione grafica F.

Laganà).

Fig. I0. Palazzo Cerra:

analisi del degrado del

prospetto su via Cavour

(elaborazione grafica $\mathrm{F}$.

Laganà).
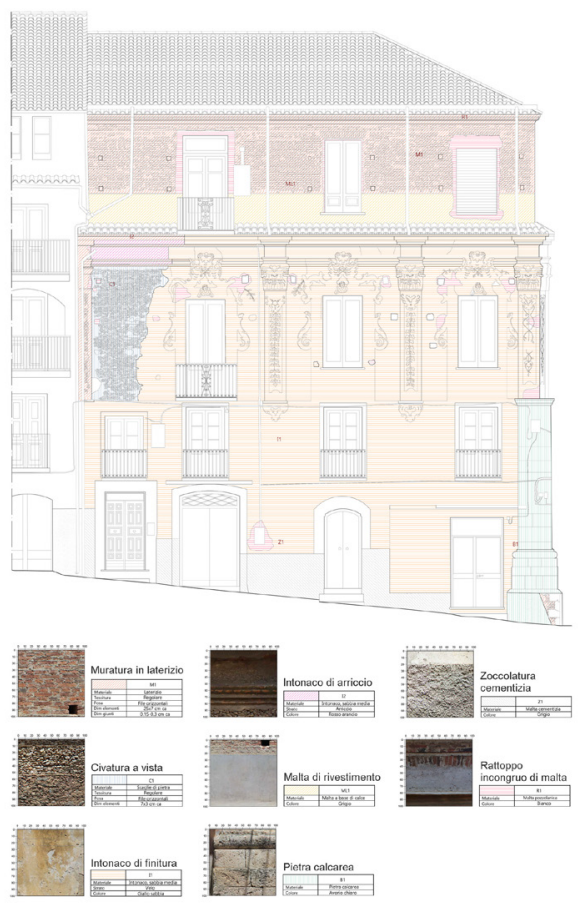

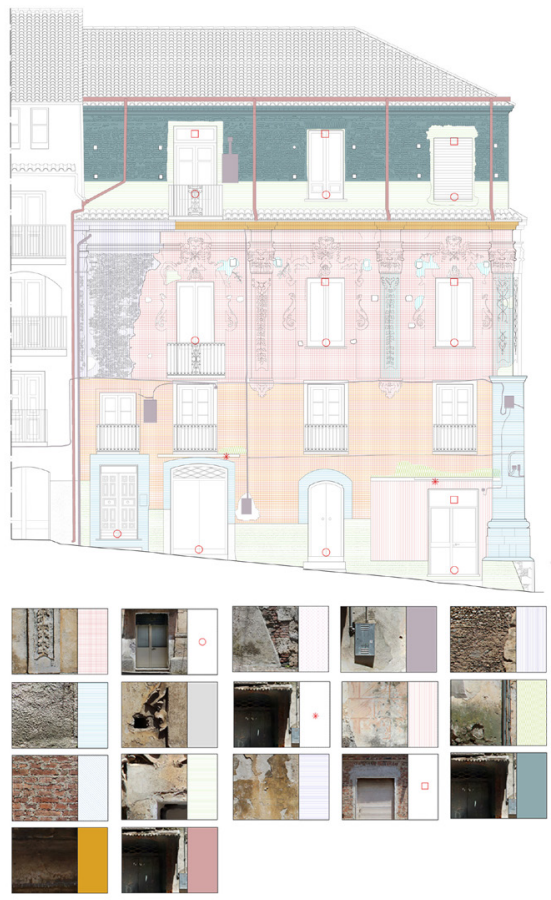




\section{Tecniche costruttive locali}

Nonostante il degrado e le lacune, il disegno barocco del fronte si è reso leggibile nei suoi caratteri essenziali, proprio attraverso il disegno, che ha registrato i partiti architettonici e gli stucchi ancora presenti al piano nobile che delineano un'architettura di stampo barocco, tipica della zona. Lo studio si è avvalso del rilievo e di testimonianze dirette, nonché del confronto con la bibliografia sulle tecniche costruttive del lametino per ricostruire la consistenza materiale dei fronti. La struttura muraria è costituita di blocchi lapidei rifiniti con strati di malte a base di calce e sabbie calcaree locali, cui si deve la tonalità degli intonaci storici, con finitura superficiale liscia e grana fine, dove sono ancora visibili resti di trattamenti cromatici

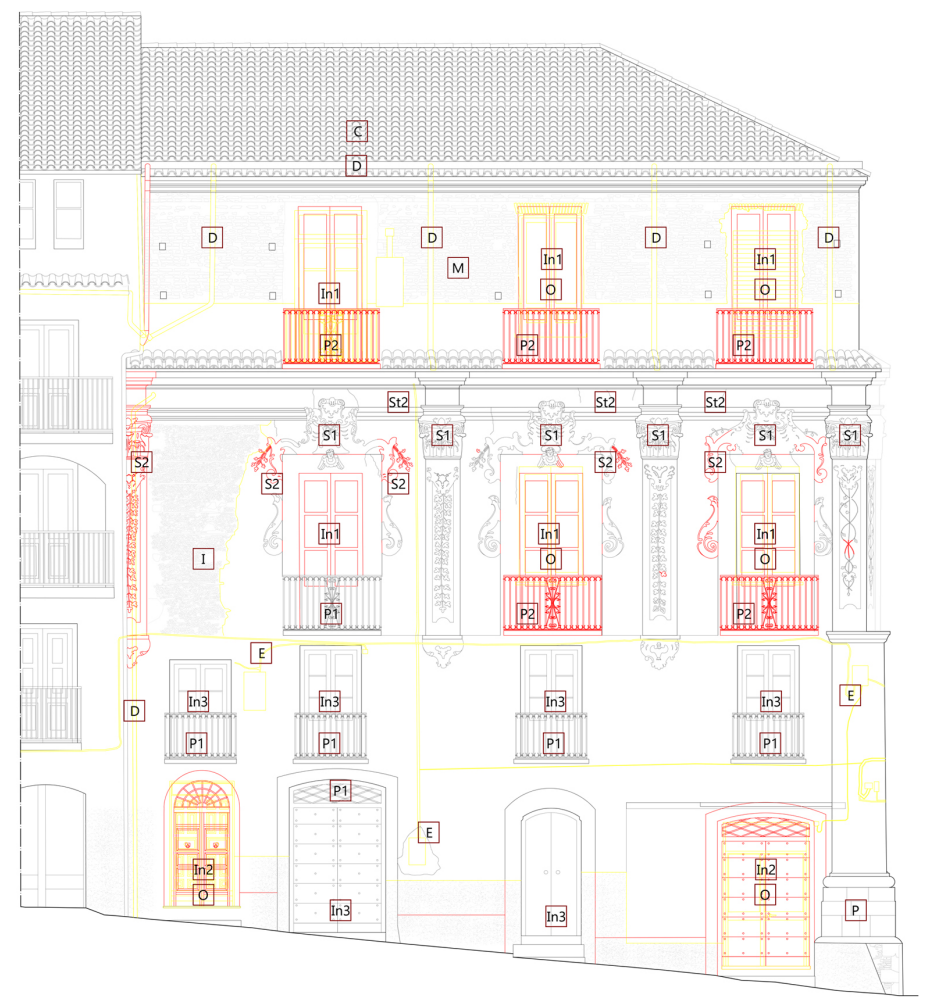

Fig. I I. Palazzo Cerra: ipotesi degli interventi de prospetto su via Cavour (elaborazione grafica F. Laganà).

\begin{tabular}{|c|c|}
\hline $\mathrm{M}$ & $\begin{array}{l}\text { Pulitura e trattamento } \\
\text { muratura sopraelevazione }\end{array}$ \\
\hline S1 & $\begin{array}{l}\text { Pulitura e trattamento } \\
\text { stucchi esistenti }\end{array}$ \\
\hline S2 & $\begin{array}{l}\text { Reintegrazione } \\
\text { stucchi }\end{array}$ \\
\hline I & $\begin{array}{l}\text { Pulitura e trattamento } \\
\text { intonaco }\end{array}$ \\
\hline$P$ & $\begin{array}{l}\text { Pulitura e trattamento } \\
\text { pietra }\end{array}$ \\
\hline
\end{tabular}

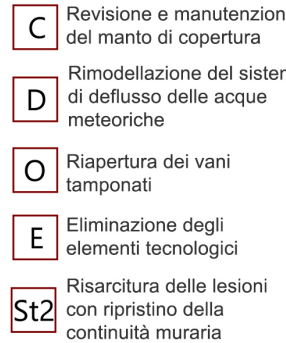

chiari realizzati con tinte a base di latte di calce. La pietra calcarea a vista caratterizza la base della parasta angolare che funge da cantonale, che, al di sopra di un alto dado, si diparte da un toro massiccio.

Tipico dell'area lametina è il paramento a civatura, composto da minuti elementi lapidei strettamente serrati, che caratterizza una porzione di struttura muraria del fronte del piano nobile verso via Cavour, visibile in una lacuna dell'intonaco. Questa tecnica di finitura dei paramenti, grazie alla lavorazione che prevedeva di inserire le scaglie lapidee nella muratura, 
solitamente era realizzata per compattare e proteggere nuclei realizzati in vriesti, ovvero con blocchi di terra cruda.

II rilievo e le campagne di rilevamento fotografico (fig. 8) hanno consentito l'analisi della consistenza complessiva dell'edificio, permettendo di identificare le principali alterazioni subite: le modifiche dei vani, soprattutto a piano terra, la zona di crollo parziale del prospetto e la ricostruzione di due campate intermedie secondo moduli non congruenti con la scansione ritmica originaria, nonché l'incongrua sopraelevazione dell'ultimo piano, evidentemente incompiuta, con un rustico paramento di mattoni in vista. Le ulteriori analisi delle facciate sulle caratteristiche materiche (fig. 9) e sullo stato di degrado (fig. I0) hanno consentito poi di definire un quadro d'interventi specifici di recupero e ripristino dei singoli elementi dei paramenti murari e dei dettagli decorativi (fig. I I).

\section{Conclusioni: una proposta per il recupero}

Sul piano teorico, la conoscenza della storia dei luoghi e delle tradizioni costruttive rappresenta il primo passo per riconoscere e riconnettere tra loro i caratteri materiali identitari che costruiscono e consolidano il senso di appartenenza ai luoghi. Il disegno e il rilievo sono in grado di colmare la distanza fisica tra i frammenti del patrimonio architettonico dispersi in contesti fortemente compromessi, ricucendoli in un racconto unitario che diventa la prima forma di riconoscimento del loro valore e quindi di una loro auspicabile salvaguardia.

Sul piano più propriamente applicativo e progettuale, il disegno ha consentito di ricostruire, attraverso la lettura degli elementi superstiti, l'apparato decorativo originario (fig. 12), riproposto come parte integrante di una più ampia ipotesi di restauro strutturale [6] che ha accettato lo stato di fatto del fronte nella sua attuale consistenza, rimodellando le bucature della facciata secondo le proporzioni originarie, restituendo dignità e visibilità a un edificio, come Palazzo Cerra, che testimonia la diffusione del linguaggio barocco in Calabria. Esso si delinea, inoltre, come un intervento perfettamente plausibile e legittimo, che, se condotto all'interno di un progetto organico di recupero del centro storico, consentirebbe alla comunità di riappropriarsi, con rinnovata consapevolezza, di un patrimonio culturale che è parte della nostra storia.
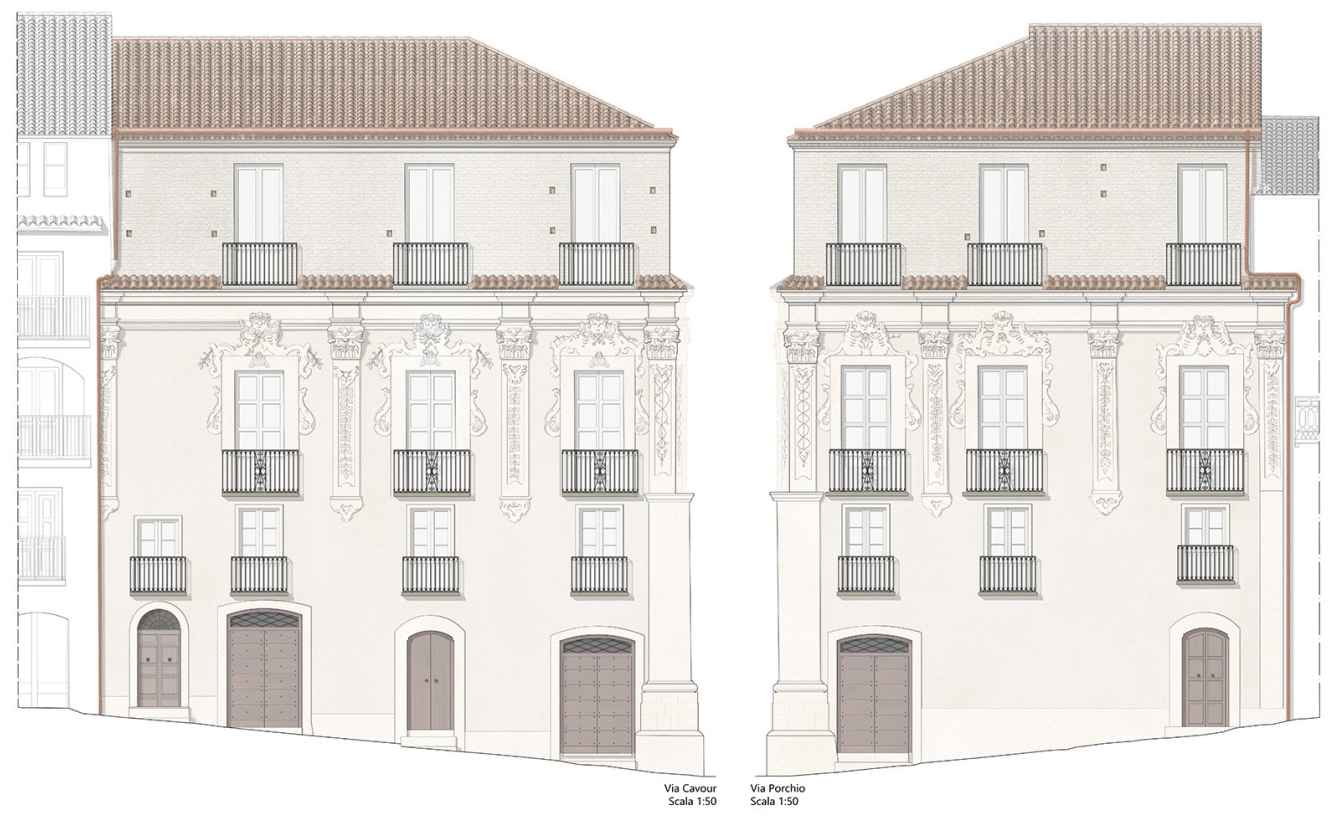


\section{Note}

[I] Studi e ricerche hanno animato un dibattito ininterrotto che, successivamente, a partire dagli anni Sessanta si è strutturato in una forma più concreta dando vita a convegni nei quali il tema del recupero dei centri storici è stato affrontato con una rinnovata attenzione al tessuto urbano e al paesaggio.

[2] L'attuale circoscrizione di Sant'Eufemia venne fondata durante il fascismo e divenne Comune autonomo nel 1935, mentre Nicastro ha origini bizantine. Anch'essa rasa al suolo dal terremoto del I638, è ricca di chiese e palazzi nobiliari.

[3] La ricerca sui centri storici in Calabria, avviata da Giovanna Spadafora e Diego Maestri, ha visto tra gli esiti il volume: Maestri, Spadafora 2008. Sul centro storico di Sambiase è stata sviluppata una ricerca, che si è tradotta in una tesi di laurea magistrale [Laganà 2020]. Nello stesso filone di ricerca s'inseriscono gli studi sui centri storici minori, Cave e Tivoli e quelli sui centri terremotati di Vezzano, Arquata e Retrosi [Canciani et al. 20 17; Canciani et al. 2019].

[4] Parte della documentazione inerente territori e centri abitati della Calabria era conservata nell'Archivio di Stato di Napoli ed è andata distrutta nel 1943

[5] Si veda: Brunori, Cretarola, Zampilli 2016, p. 42.

[6] Per restauro strutturale si intende "un intervento che conserva le tecniche costruttive e i materiali tradizionali" [Francini, Colucci, Palermo, Viapiana 2019, p. 39].

\section{Riferimenti bibliografici}

Bonacci P. (Dicembre 1988). Le origini storiche di Sambiase - parte I. Città, pp. 44-46.

Bonacci P. (Gennaio 1989a). Le origini storiche di Sambiase - parte 2. Città, pp. 44-47.

Bonacci P. (Febbraio 1989b). Le origini storiche di Sambiase - parte 3. Città, pp. 36-38.

Bonacci P. (Marzo 1989c). Le origini storiche di Sambiase - parte 4. Città, pp. 42, 43.

Borrello E. (1948). Sambiase. Ricerche per la storia della città e del suo territorio. Roma:Temesa Editrice.

Brunori G., Cretarola A., Zampilli M. (20 I 6). Tivoli: lettura di una città. In U+D urbanform and design n. 05/06-20 I6, pp. 32-49.

Canciani M., Sturm S., G. Fioravanti (2020). Il cielo sopra Foligno. Rilievo 3D del centro storico tramite tecnologia aeromobile a pilotaggio remoto (APR). In Sturm S. (a cura di). Foligno. I palazzi e la città dal Rinascimento al Neoclassico. Perugia: Quattroemme. pp. 34I-355.

Canciani M. et al. (2017). Methodology of analysis and virtual recomposition: the case of Retrosi (Amatrice, Italy). In Amoruso G. (a cura di). Putting tradition into practice: heritage, place and design. Milano: Springer International, pp. 75-83.

Canciani M., et al. (2019). Cartografia aggiornata del centro storico di Tivoli: contributi al GIS del territorio del Comune. In: (a cura di): Martines R., Pallottino E., TIVOLI, UN LABORATORIO URBANO leri, oggi, domani. Roma: Edizioni Roma TrE-Press, pp. 97- 126.

Chen J., Clarke K. C. (20I6). Rapid 3D modeling Using photogrammetry applied to Google Earth. In Indoor 3D Mapping, Pittsburgh, Pennsylvania: AutoCarto.

Cozzetto F. (200 I). Città di Calabria e hinterland nell'età moderna: demografia e strutture amministrative e sociali. Rubbettino Editore.

D'Avino, V. (1848). Cenni storici sulle chiese arcivescovili, vescovili, e prelatizie (nulluis) del Regno delle Due Sicilie raccolti, annotati, scritti per l'ab.Vincenzo D'Avino, dalle stampe di Ranucci.

De Luca R., Gigliotti V. et al. (2016). Spectroscopic, microchemical and petrographic analyses of plasters from ancient buildings in Lamezia Terme (Calabria, Southern Italy). In Spectrochimica Acta Part A: Molecular and Biomolecular Spectroscopy, I 53, I 84193.

Francini M., Colucci M., Palermo A., Viapiana M.F. (2019). I centri storici minori. Strategie di rigenerazione funzionale. Milano: FrancoAngeli.

Guidoboni E. (20 I7). II valore della memoria. Terremoti e Ricostruzioni in Italia nel lungo periodo. In Quellen und Forschungen aus italienischen Archiven und Bibliotheken, vol. 96/2016.

Laganà F. (2020). Conoscere per tutelare e valorizzare il patrimonio architettonico: il centro storico di Sambiase e Palazzo Cerra, analisi, rilievo e conservazione. Tesi di laurea magistrale in Architettura-Restauro, relatore M. Canciani; correlatori P. Brunori, G. Spadafora. Dipartimento di Architettura di Roma Tre.

Maestri D., Spadafora G. (2016). Ambiente e architetture di San Giovanni in Fiore. Roma: Gangemi Editore.

Mazza F. (200 I). Lamezia Terme: storia, cultura, economia (Vol. I I). Soveria Mannelli: Rubbettino Editore.

Paletta M.G. (2007) Indagini sul patrimonio in terra nel lametino. Tesi di laurea. Relatore prof. S. Mecca, correlatori prof. C. Cuomo, arch. L. Dipasquale. Università degli Studi di Firenze. 
Panarello M. (2005). Architettura residenziale del Sei e Settecento in Calabria, Note per una catalogazione regionale. Reggio Calabria: liriti Editore.

Panarello M. (2009). Architettura e decorazione nelle dimore nobiliari calabresi del '600 e '700, in Atlante Tematico del Barocco in Italia, II sistema delle residenze nobiliari - Italia meridionale. Roma: De Luca editori d'Arte.

Proto N., Cicione F. (2005). L'edilizia di tradizione rurale nella conformazione delle aree urbane lametine. In B. Biondi (Ed.) Ist international research seminar on architectural heritage and sustainable development of small and medium cities in south Mediterranean regions: results and strategies of research and cooperation, pp. 495-509. Pisa: Edizioni ETS.

Remondino F., El-Hakim S. (2006). Image-based 3D modelling: a review. In The Photogrammetric Record, Vol.2I (I I 5), pp. 269-291.

\section{Autori}

Marco Canciani, Università degli Studi Roma Tre, marco.canciani@uniroma3.it

Giovanna Spadafora, Università degli Studi RomaTre, giovanna.spadafora@uniroma3.it

Paola Brunori, Università degli Studi Roma Tre, paola.brunori6@virgilio.it

Francesca Laganà, Università degli Studi RomaTre, lagana.fa@gmail.com

Per citare questo capitolo: Canciani Marco, Spadafora Giovanna, Brunori Paola, Laganà Francesca (202 I). II lessico formale dell'architettura storica: il caso del centro storico di Sambiase/The formal lexicon of historic architecture: the case of the historic center of Sambiase. In Arena A., Arena M., Mediati D., Raffa P. (a cura di). Connettere. Un disegno per annodare e tessere. Linguaggi Distanze Tecnologie. Atti del $42^{\circ}$ Convegno Internazionale dei Docenti delle Discipline della Rappresentazione/Connecting. Drawing for weaving relationship. Languages Distances Technologies. Proceedings of the $42^{\text {th }}$ International Conference of Representation Disciplines Teachers. Milano: FrancoAngeli, pp. 285-306. 


\title{
The Formal Lexicon of Historic Architecture: the Case of the Historic Center of Sambiase
}

\author{
Marco Canciani \\ Giovanna Spadafora \\ Paola Brunori \\ Francesca Laganà
}

\begin{abstract}
The 1648 earthquake almost completely destroyed Sambiase, a district of Lamezia Terme, in Calabria, and profoundly shaped its history and began a long and never definitively concluded reconstruction process.

The study of the urban fabric realized using photogrammetric and 3D surveys and carried out with techniques 'at distance', together with the analysis of historical documentation, has allowed us to reveal precious evidence of the Calabrian Baroque architectural lexicon within a multiform and disordered agglomeration. In particular, the study on the scale of the building, conducted on Palazzo Cerra, highlighted the changes that occurred over the centuries and allowed us to hypothesize the various historical and constructive phases. Thanks to this study we can again reaffirm the role of drawing as an instrument in the identification and re-appropriation of the identitary characteristics of a site, with the aim of bridging the distance, in time, among the fragments of urban and architectural history scattered within contexts to which they are no longer related, to perceive them as being part of a continuous story. The study also recognizes a further property of the drawing, overcoming physical distances, now rendered greater by the restrictions due to the pandemic, thanks to the use and sharing of methodologies based on digital technologies.
\end{abstract}

Keywords

Sambiase, 3D survey, Palazzo Cerra, Calabrian Baroque.

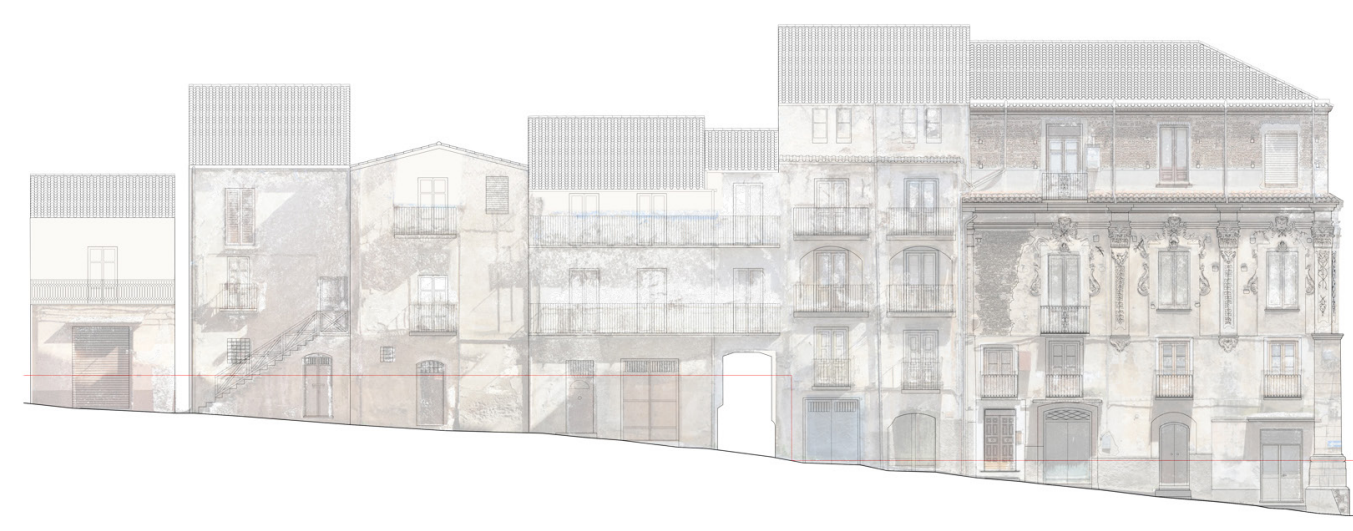




\section{Introduction}

Despite the fact that the debate in Italy on the safeguard of historic centers and the need for the recognition and preservation of the identifying characteristics of the territories and constructions, began as far back as the end of the nineteenth century [I], economic and political motives, combined with urgent needs of contingent problems, have determined profound differences in the methods and the times of interventions in individual contexts. Only since the late 1990s has Calabria, in particular, seen an intensification of specific activities aimed at financing projects for the requalification and enhancement of historic centers, together with a view to cultural and tourism opportunities. It should, however, be emphasized that the historical-political, economic, and social reasons, added to that, the fragility of the territory itself -which has witnessed numerous earthquakes destroy entire inhabited centers from I 108 to the latest in 1908- have ensured that the Calabrian architectural heritage appears fragmented into single episodes that, though valuable, were almost invisible within contexts which have become unrelated. A territory, therefore, which many times has had to face the void left by the loss of human lives and its own material history, and then the phenomena of migration, abandonment, and return migration that have heavily conditioned the interventions on the scale of buildings. In this context, the study on the historic center of Sambiase (one of the three municipalities which, together with Nicastro and Sant'Eufemia, since 1968 have become districts of the city of Lamezia Terme [2]) stands as a further element in the research on minor historic centers of Calabria, and elsewhere, for some time now carried out by the Department of Architecture [3].

Fig. I. Sambiase historic center: photogrammetric survey from Google

Earth, axonometric view of the 3D model (elaboration by M. Canciani).

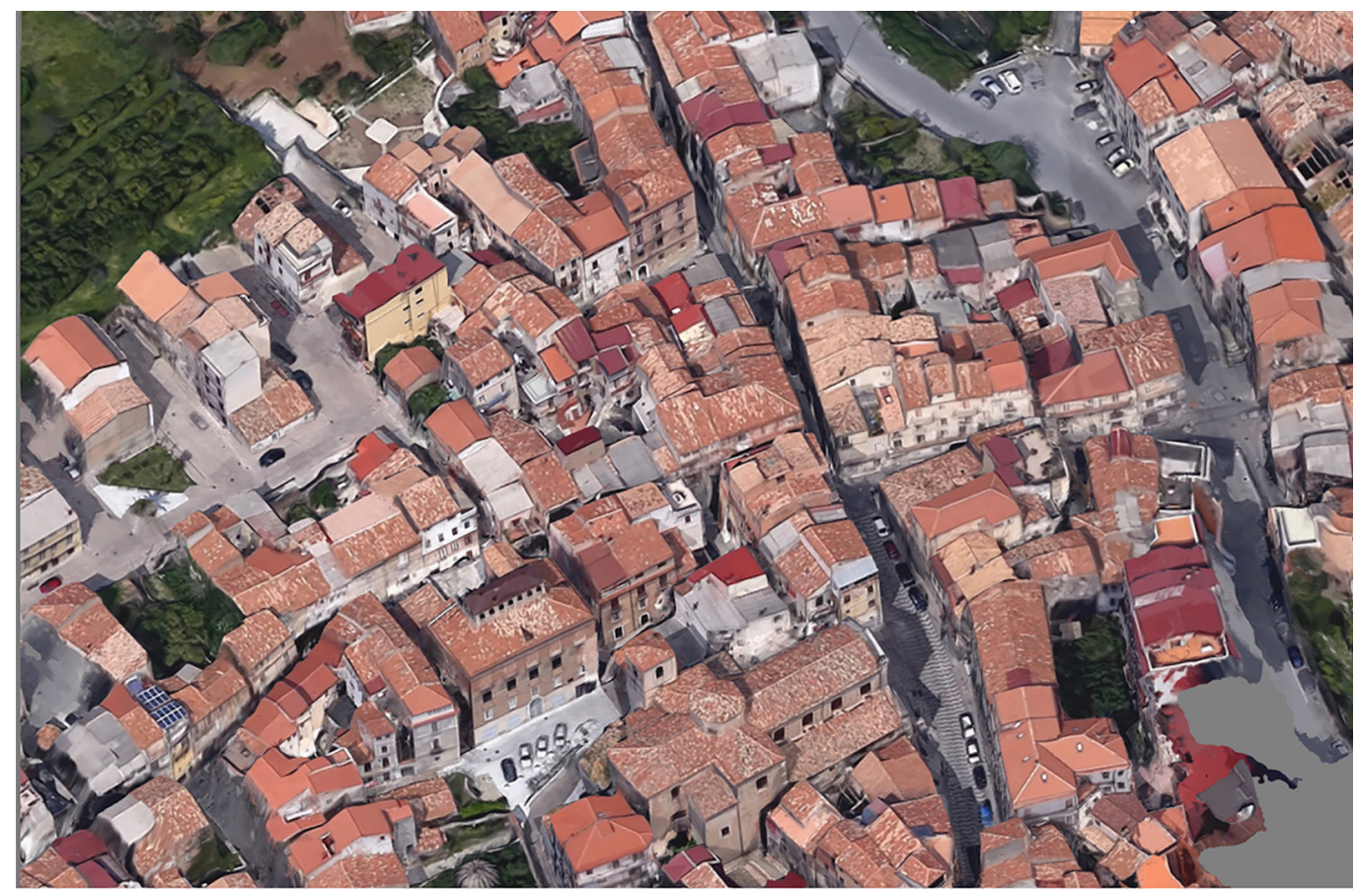

\section{The research method}

The methodology used is based on the consolidated integration between historical research and survey in three phases: in the first, made difficult by the lacunose documentation $\left[{ }^{4}\right]$, the acquired cartography was integrated with a detailed examination of the bibliographic and iconographic sources. The second concerned the 3D survey of the urban fabric and 
Fig. 2. Sambiase historic center: orthophoto corrected by Google Earth (elaboration by M. Canciani). buildings selected as a case study. For the work on an urban scale, the impossibility of returning to the site to complete the surveys, given the health directives due to the pandemic, led to the implementation of a procedure that makes use of the available technologies to bridge physical distances: the images acquired by the Google Earth application were used [Canciani, Fioravanti 2020, pp. 341-355; Chen, Clark 2016] to build a geo-referenced photogrammetric model, with a degree of definition compatible to a scale of I: 500 (fig. I) Both the survey on an urban scale and on the scale of buildings were elaborated using customary principles, based on the procedures of SFM (Structure from Motion) speditive photogrammetry [Kraus 2007; Remondino, El-Hakim 2006], and the use of the photogrammetry program Metashape.

In the third phase, all the data acquired via the various survey procedures, including those that carried out directly on-site, were integrated with those obtained from the historical documentation, with the added result of obtaining a geo-referenced roofing plan (fig. 2) helpful in understanding the building typologies that characterize the historical urban fabric of Sambiase- and some detailed drawings of the facades. The latter, accompanied by the sections, proved to be indispensable to comprehend the formal and architectural lexicon characterizing the historic buildings of Sambiase, and, in particular, Palazzo Cerra.

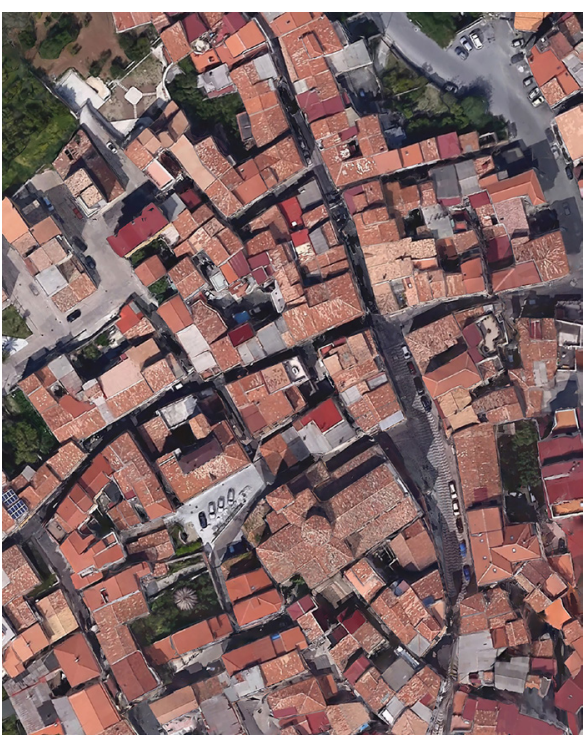

\section{The urban structure of Sambiase today}

For the city of Sambiase the 1684 earthquake represented not only the instant of the complete destruction of its historic center but also the beginning of a long phase of reconstruction of the entire urban structure, which at first glance has never been definitively concluded [Guidoboni 2017, p. 4I6]. Sambiase, in 1948, 300 years after the earthquake, appeared "to have been rebuilt, but unfortunately with no any hygienic or aesthetic criteria, narrow streets, microscopic piazzas, long lines of rural houses..." [Borrello 1948pp. 252, 253] (fig. 3). Since that date, more than 70 years ago, the image that one perceives today is that of a historic center in which the historicized elements are hidden from the incongruous modern ones, where the 'finished' buildings can be counted on the fingers of one hand, in a "state of incompleteness and semi-abandonment" [Proto, Cicione 2005, p. 507], which represents a particular characteristic of Calabrian historical centers, that "architectural incompleteness" that constitutes a lexicon, albeit contradictory, of the true Lametino genius loci [Proto, Cicione 2005, p. 503]. 
Under these conditions of difficult interpretation, it is possible, with careful observation and a survey, to identify those elements that represent the identifying characteristics of a site, referring to the historical formative phases, the dwelling structures, the building fabric, and the characteristics of the built [5]:-

The refined wrought iron works, the plastic molded frames of the windows, the ashlar doors, in apparent contrast with the unfinished facades in exposed brickwork, constitute effective expressions of a formal lexicon typical of the Calabrian Baroque [Panarello 2009, pp. | | 2- | 24]. These well cared for elements do not correspond to the same care in construction techniques for seismic risk mitigation: few safeguards were adopted including chain, only recently adopted, scarp walls on the taller buildings, external stairwells to act as buttresses, and still only a few buildings built with adequate construction techniques (height restriction and significantly thick masonry for the lower floors), which, in part, we find in the Royal Instructions of Bourbon Regulations, so-called Pignatelli, of I 783 [Guidoboni 20 17, p. 436].

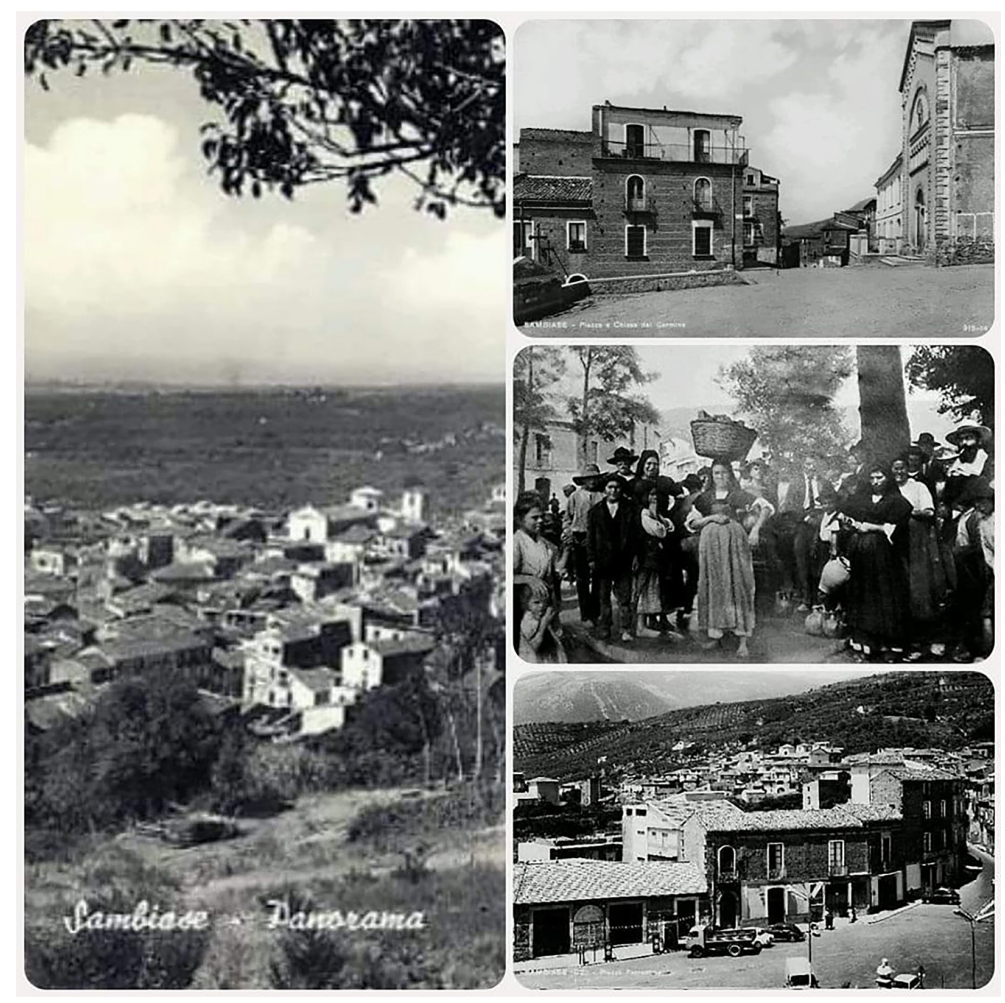

In the elaboration of the plan (fig. 4), the different buildings, where additions, extensions, and superfetations have been removed, are highlighted, which constitute the building types dating back to the first phases following the earthquake: the basso, (low) a one-level housing unit, represents the intramoenia transposition of the rural house [Proto, Cicione 2005, p. 498]; the vignano, which sees the insertion of an upper room and an external staircase; the palazziata, an aristocratic property organized on three or four floors, with some decorative elements of value on the facades; the palazzo nobiliare (noble palace), such as Palazzo Cerra or Palazzo Nicotera, characterized by a decorated facade and an internal courtyard, which, in a subsequent phase, is modified into a shared internal space, and called vaglio (figs. 5, 6). As of that period, the road network of the historic center underwent a clear transformation: from a dense network of alleys enclosed by two compact fronts, with few open spaces, only near the churches and palaces, to a network that expands in the numerous spaces, causing interruptions and visual openings in the city paths. 


\section{Hypothesis on the phases of expansion of the housing in Sambiase}

The consulted bibliography [D'Avino 1848, Bonacci 1988; 1989a; 1989b; 1989c; Borrello 1948] situates the first settlement of Sambiase in the IOth century, around the Basilian monastery of San Biagio, when buildings of a strictly rural character began to be built near the monastery, assuming, however, a formal lexicon, peculiar to the city's architecture. [Proto, Cicione 2005, p. 498]. Though much attention has been paid to the history of churches and convents, very little is the evidence of architectural emergencies and none the studies on the urban fabric. In this regard, in the first phase of the research, the consultation of the State Archives of Catanzaro and the Municipal Archives of Lamezia Terme yielded the retrieval of the Onciario Cadastre of 1783, the Cadastre of 195I, and a series of notarial documents, useful in formulating the hypotheses on the stages of expansion of the inhabited area. This work was preparatory to the subsequent analysis of the case study.

Fig. 4. Planimetry with the main building type highlighted: in red the religious constructions, in yellow the 'bassi', in orange the 'vignani', in green the 'palazziate' and in blue the 'palazzi nobiliari'; the 'vagli' (plural of 'vaglio') are highlighted in brown (graphic

elaboration by F. Laganà).

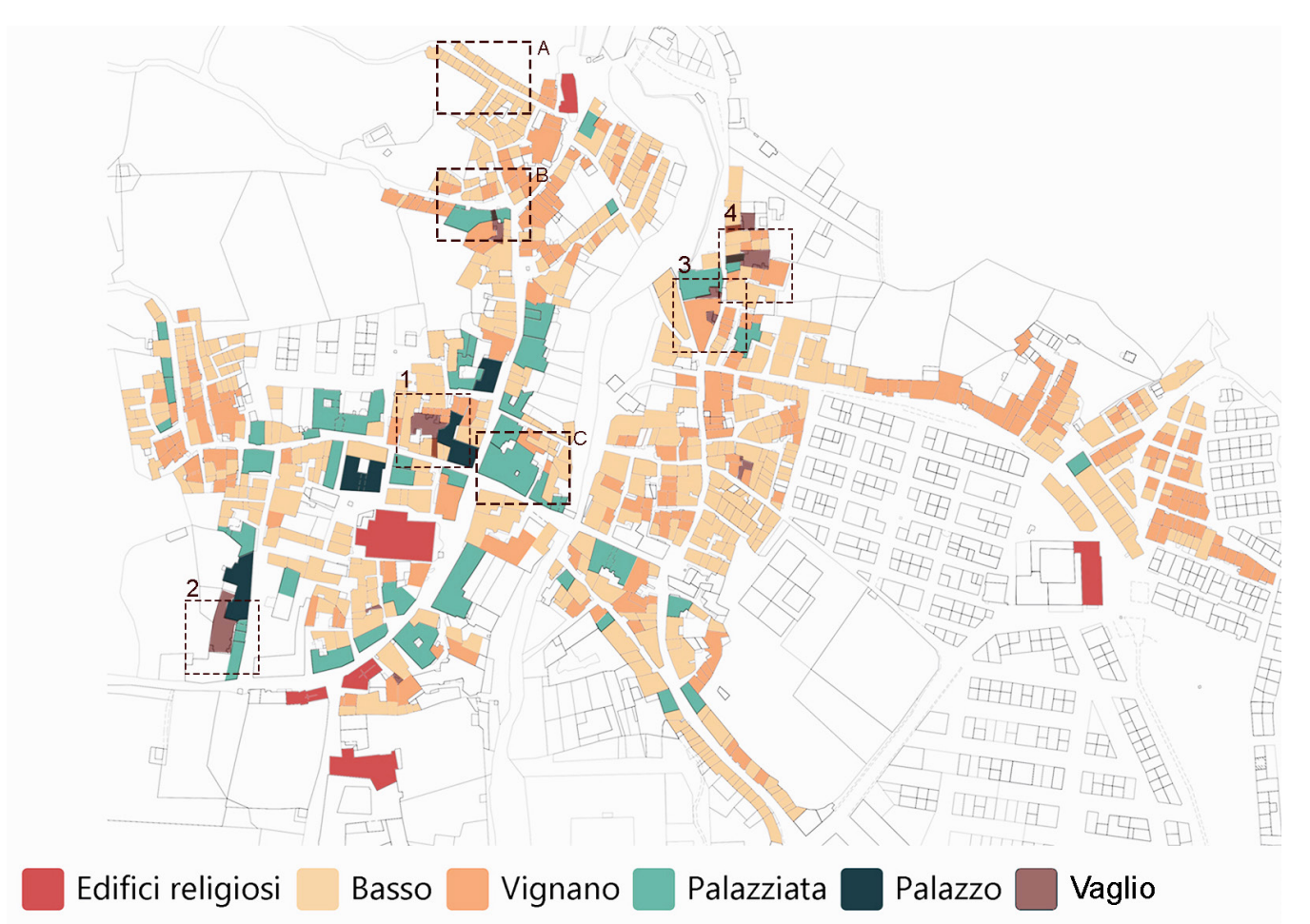

\section{Palazzo Cerra}

Of the noble palaces studied, Palazzo Cerra, formerly Palazzo Fiore, is certainly one of the most interesting; what remains of the decorative stucco details of the facades still represents today the testimony of the Calabrian Baroque (fig. 7). Built between 1760 and 1780, it became the property of the Mazzei-Cerra family at the end of the nineteenth century and divided into several residential units at the beginning of the twentieth century, thus sharing the destiny with other noble palaces following the changing economic and social conditions. The reconstruction of the original planimetric extension of Palazzo Cerra originated with the analysis of the surviving evidence and the comparison with Palazzo Nicotera, with which it shares some similarities. The current layout, in fact, may be the result of at least two phases of modifications of the original building, which one entered through a covered passage that led into a courtyard exclusively annexed to the palace and overlooked by the service 
Fig. 5. List of the main building types, highlighted with a letter and a pane in the plan of fig. 4: the 'basso' (A) the "vionano' (B) and the 'polazziato' (C) with indications of the intended use Green defines a multifunctional area, red the living area, yellow the storage area and blue the sleeping are (graphic elaboration by F. Laganà)

Fig. 6. List of some 'vagli', called atriums in the

toponymy indicated with a number and a frame a number and a frame in I Cavour; 2. Atrium Giuseppe Verdi; 3. Atrium I Ferruccio; 4. Atrium III Ferruccio (graphic elaboration by F. Laganà)

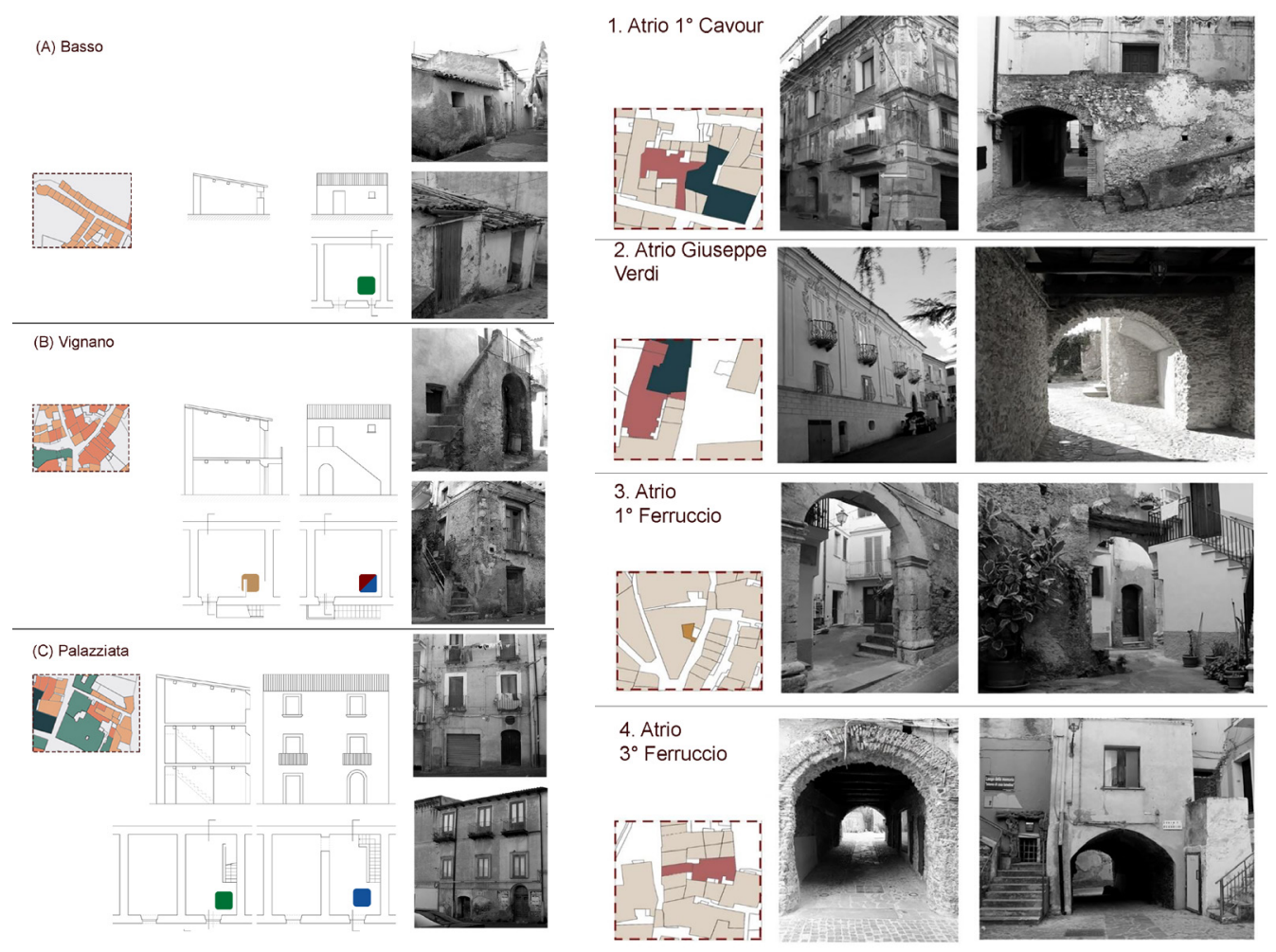

rooms and the staircase/loggia access to the first floor, still with traces of the precious stucco decoration.

Probably in the second half of the nineteenth century, there was a heavy restructuring of a portion of the building, and the design of the facade lost its unity. But the intervention that definitely corrupts the original image of the building is the elevation built in the mid-twentieth century.
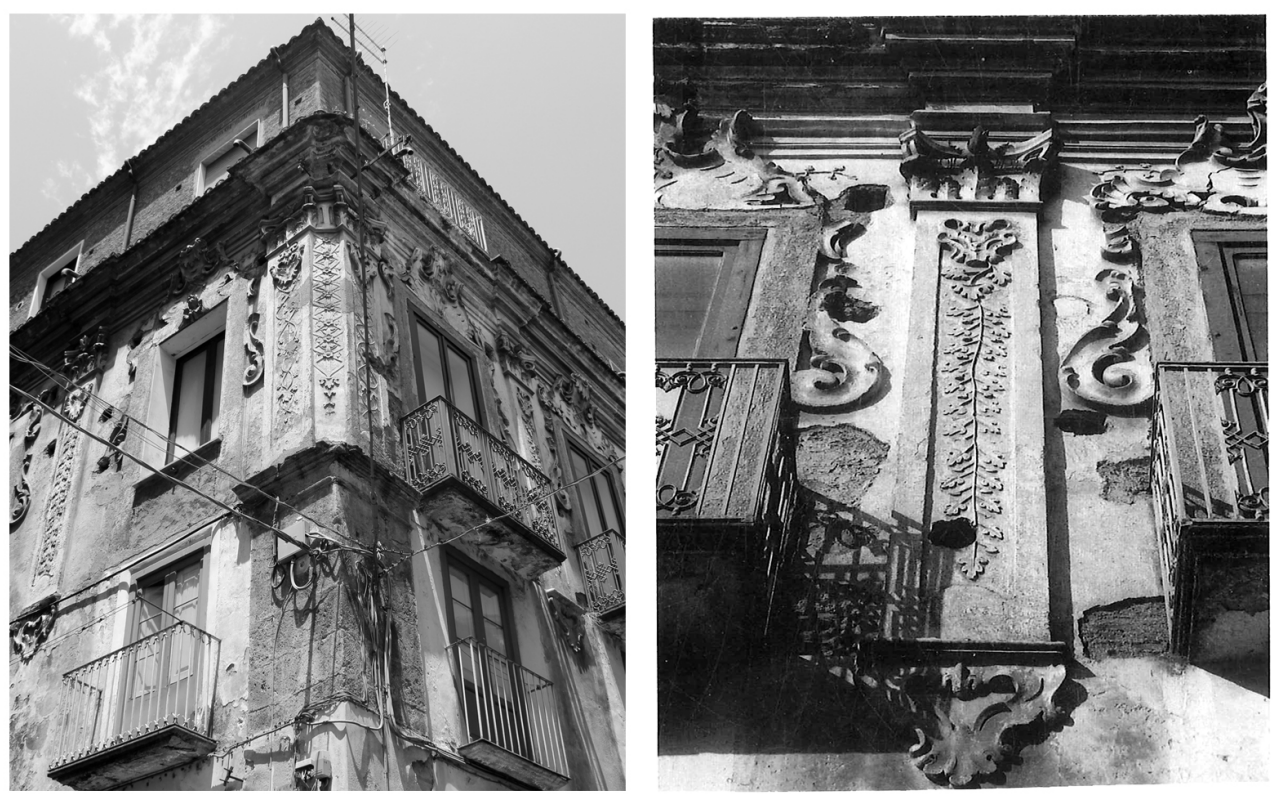
Fig. 8. Palazzo Cerra: survey of the elevations

on via Cavour and

elaboration by F. Laganà).
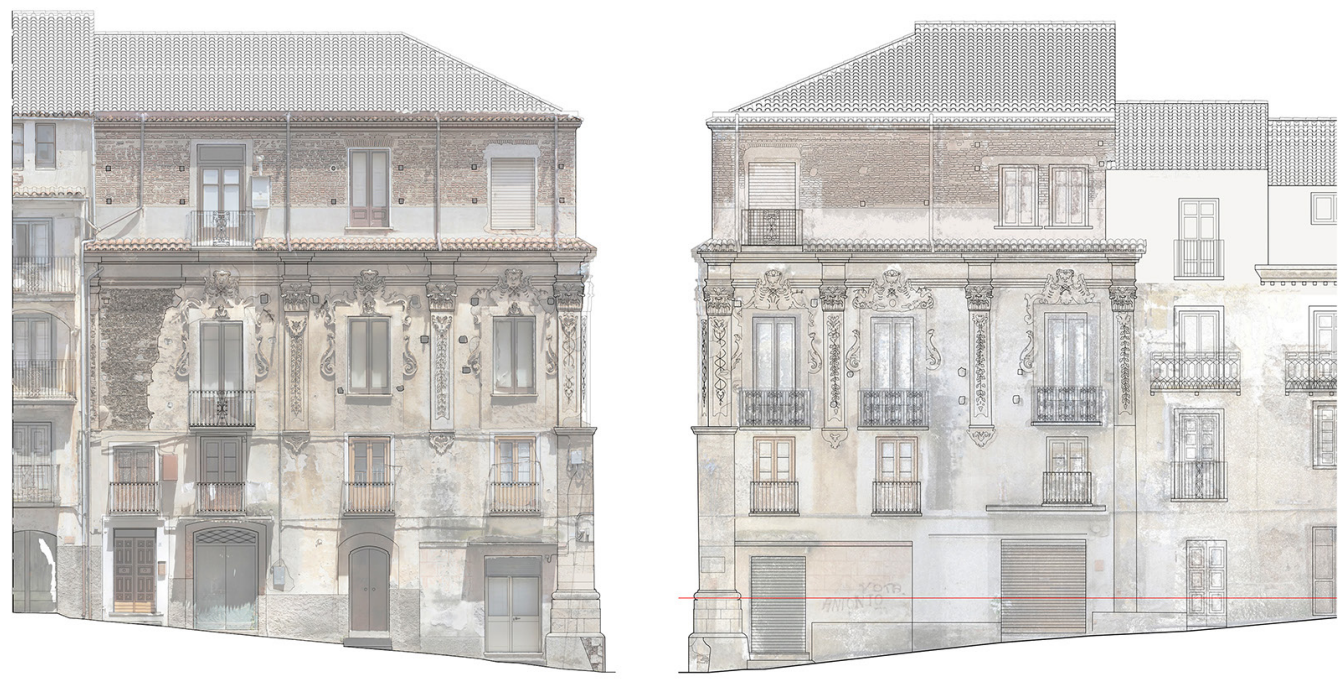

Fig. 9. Palazzo Cerra:

analysis of the materials of

the façade on via Cavour

(graphic elaboration by F.

Laganà)

Fig. 10. Palazzo

Cerra: analysis of the

deterioration of the

façade on via Cavour

(graphic elaboration by

(graphic el
F. Laganà).
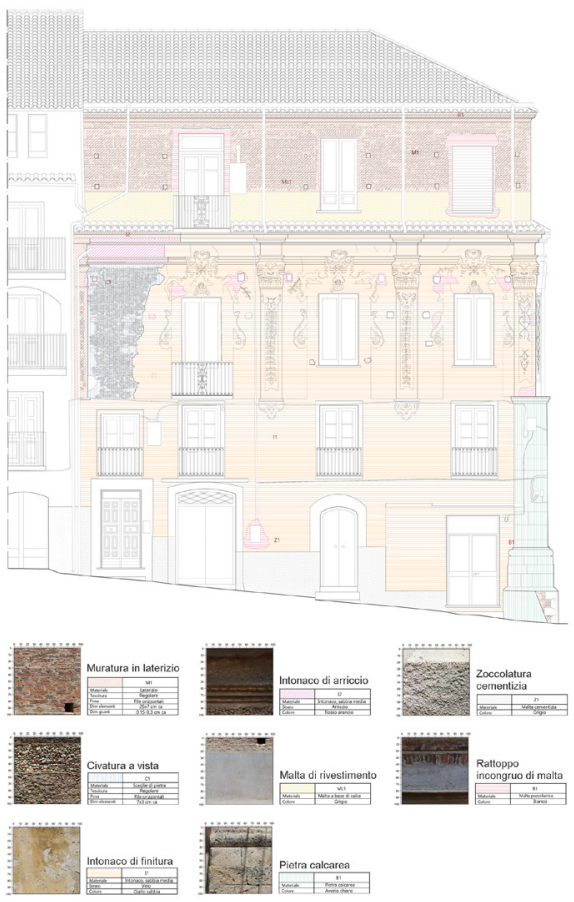

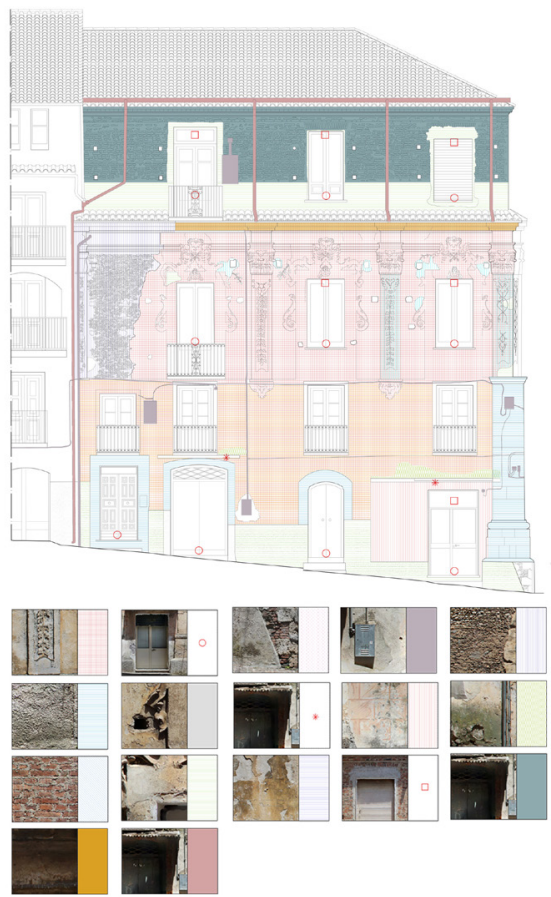




\section{Local construction techniques}

Despite the deterioration and the gaps, the baroque design of the front has become legible in its essential characters, precisely through the design, which recorded the architectural elements and the stuccoes still present on the main floor that delineate a baroque-style architecture, typical of the area. The research availed itself of the survey and direct evidence, as well as an examination of the bibliography on the construction techniques in Lametino to reconstruct the material consistency of the facades. The masonry is made up of stone blocks finished with layers of mortar based on lime and local calcareous sands, due to which is the hue of the historic plasters, with a smooth and fine-grained surface finish, where remains of

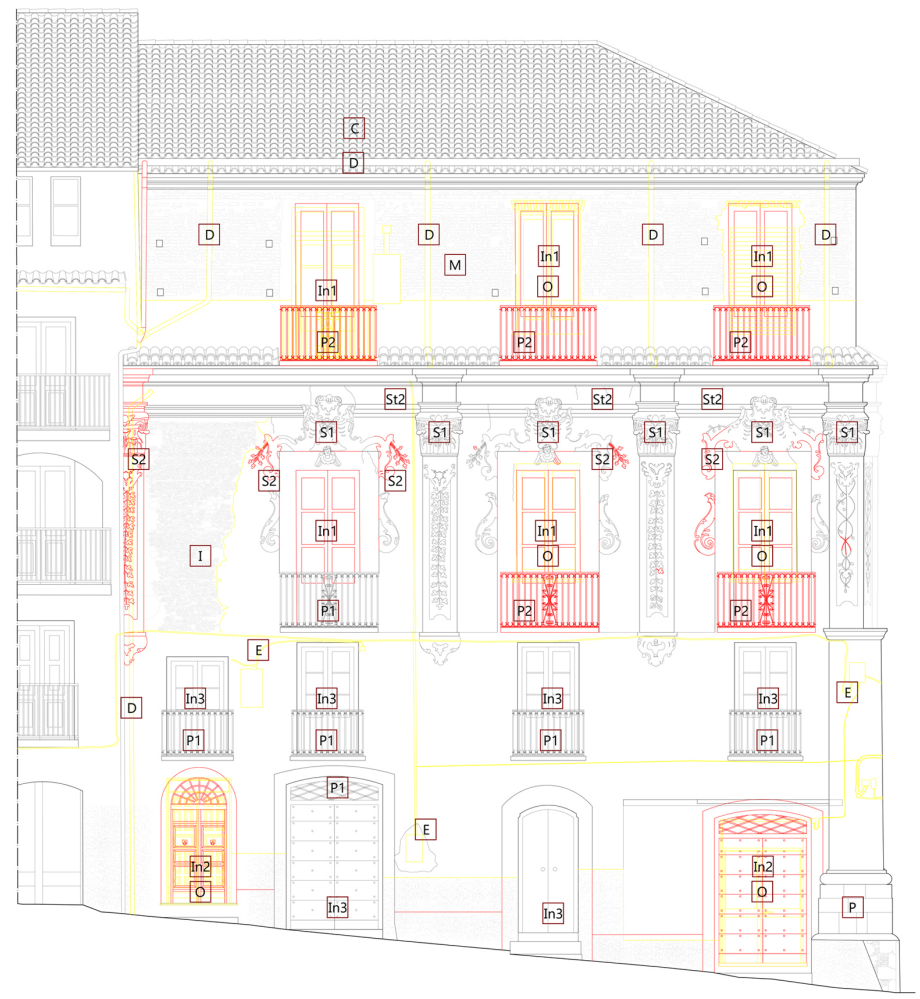

\begin{tabular}{|c|c|}
\hline $\mathrm{M}$ & $\begin{array}{l}\text { Pulitura e trattamento } \\
\text { muratura sopraelevazione }\end{array}$ \\
\hline S1 & $\begin{array}{l}\text { Pulitura e trattamento } \\
\text { stucchi esistenti }\end{array}$ \\
\hline S2 & $\begin{array}{l}\text { Reintegrazione } \\
\text { stucchi }\end{array}$ \\
\hline I & $\begin{array}{l}\text { Pulitura e trattamento } \\
\text { intonaco }\end{array}$ \\
\hline$P$ & $\begin{array}{l}\text { Pulitura e trattamento } \\
\text { pietra }\end{array}$ \\
\hline
\end{tabular}

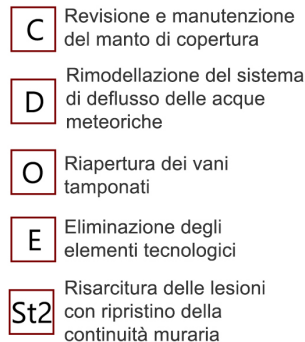

$$
\begin{aligned}
& \text { In1 } \begin{array}{l}
\text { Sostituzioni delle } \\
\text { porte finestre }
\end{array} \\
& \text { In2 } \begin{array}{l}
\text { Sostituzioni delle porte } \\
\text { a piano terra }
\end{array} \\
& \text { In3 } \begin{array}{l}
\text { Restauro degli } \\
\text { infissi }
\end{array} \\
& \text { P1 } \begin{array}{l}
\text { Pulitura e trattamento } \\
\text { dei parapetti e sopraluce }
\end{array} \\
& \text { P2 } \begin{array}{l}
\text { Integrazione con parapetti } \\
\text { e sopraluce analoghi a } \\
\text { quelli esistenti }
\end{array}
\end{aligned}
$$

light chromatic processing with dyes based on limewash are still visible. The exposed limestone characterizes the base of the corner pilaster that functions as a cantonal, which, above a dado, departs from a massive torus.

Typical of the Lametine area is the civatura facing, a rendering composed of minute stone elements tightly bound, which characterizes a portion of the wall structure of the facade of the noble floor facing via Cavour, visible in a gap in the plaster. This technique of finishing the 
elements, thanks to the process involving inserting the stone flakes into the masonry, was usually made to compact and protect nuclei made of vriesti, or blocks of adobe.

The analysis of the overall consistency of the building was possible from the survey and photographic surveys (fig. 8), making it possible to identify the main alterations undergone: the modifications of the rooms, especially on the ground floor, the areas of partial collapse of the façade and the reconstruction of two intermediate spans following modules that are not congruent with the original rhythmic pattern, as well as the incongruous elevation of the top floor, obviously unfinished, with a rustic exposed brick facing. Further analyses of the material characteristics of the facades (fig. 9) and their state of decay (fig. 10) made it then possible to define a framework of specific interventions for the recovery and restoration of the individual elements of the wall facings and decorative details (fig. II).

\section{Conclusion: a proposal for its restoration}

On a theoretical level, knowing the history of places and building traditions represents the first step in recognize and associate the identifying material characteristics that create and consolidate the sense of belonging to a location. The drawing and the survey can bridge the physical distance between the fragments of architectural heritage dispersed in highly compromised contexts, rejoining them in a unitary story that becomes the first form of recognition of their value and thus the desirability of their preservation.

On a more properly design level, the drawing makes it possible to reconstruct, through a reading of the surviving elements, the original decorative aspect (fig. 12), re-proposed as an integral part of a broader hypothesis of structural restoration [6] that has accepted the current state of the facade in its present consistency, remodeling the openings of the facade according to the original proportions, restoring dignity and visibility to a building, like Palazzo Cerra, testimony to the spread of the Baroque language in Calabria. It is also delineated as a perfectly plausible and legitimate intervention, which, if carried out within an organic project for the recovery of the historic center, would allow the community to regain possession, with renewed awareness, of its cultural heritage which is a part of our history.

Fig. 12. Palazzo Cerra: hypothesis of the original decorative apparatus of the elevations on via Cavour and via Porchio (graphic elaboration by F. Laganà).
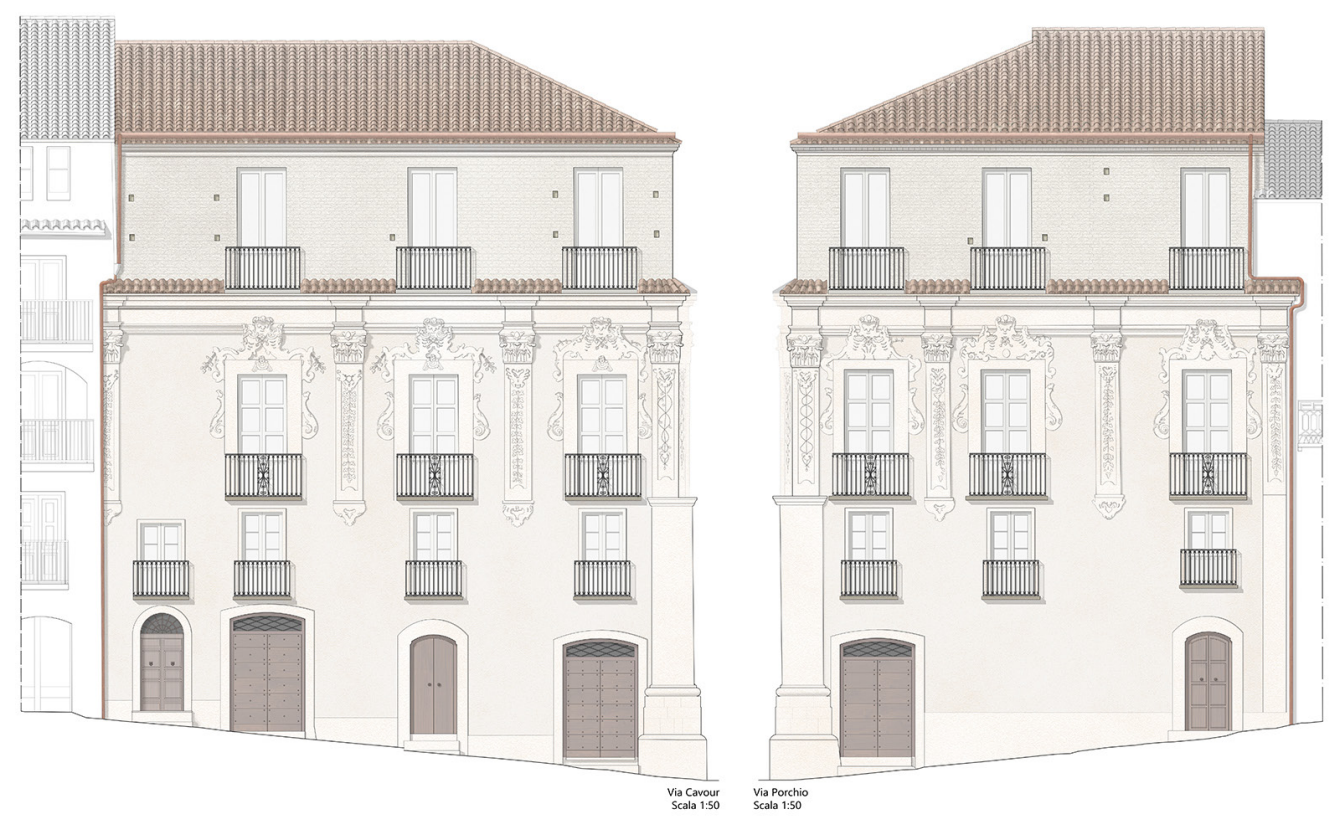


\section{Notes}

[I] Studies and research have animated an ongoing debate which, subsequently, beginning in the 1960s, has become more concretely structured, giving rise to conferences in which the theme of the recovery of historic centers was addressed with renewed attention to the urban structure and landscape.

[2] The current district of Sant'Eufemia was founded during the Fascist regime and became an independent municipality in 1935, while Nicastro has Byzantine origins. Also razed to the ground by the earthquake of 1638 , it it has numerous churches and noble palaces.

[3] Among other results from the research on historic centers in Calabria, initiated by Giovanna Spadafora and Diego Maestri, was the volume Maestri, Spadafora, 2008. A research was undertaken on the historic center of Sambiase, resulting in a Master's degree thesis [Laganà 2020].The studies on the minor historical centers, Cave and Tivoli and those on the earthquake centers of Vezzano, Arquata and Retrosi are included in the same line of research [Canciani et al. 2017, Canciani et al. 2019].

[4] Part of the documentation concerning the territories and inhabited centers of Calabria was housed in the State Archives of Naples and destroyed in 1943.

[5] See: Brunori, Cretarola, Zampilli 2016, p. 42.

[6] The term "structural restoration" is used to mean "an intervention that preserves traditional construction techniques and materials" [see Francini, Colucci, Palermo, Viapiana 2019, p. 39].

\section{References}

Bonacci P. (Dicembre 1988). Le origini storiche di Sambiase - parte I. Città, pp. 44-46.

Bonacci P. (Gennaio 1989a). Le origini storiche di Sambiase - parte 2. Città, pp. 44-47.

Bonacci P. (Febbraio 1989b). Le origini storiche di Sambiase - parte 3. Città, pp. 36-38.

Bonacci P. (Marzo 1989c). Le origini storiche di Sambiase - parte 4. Città, pp. 42-43.

Borrello E. (1948). Sambiase. Ricerche per la storia della città e del suo territorio. Roma:Temesa Editrice.

Brunori G., Cretarola A., Zampilli M. (20 I 6). Tivoli: lettura di una città. In U+D urbanform and design n. 05/06-20 I 6, pp. 32-49.

Canciani M., Sturm S., G. Fioravanti (2020). Il cielo sopra Foligno. Rilievo 3D del centro storico tramite tecnologia aeromobile a pilotaggio remoto (APR). In Sturm S. (a cura di). Foligno. I palazzi e la città dal Rinascimento al Neoclassico. Perugia: Quattroemme. pp. 34I-355.

Canciani M. et al. (2017). Methodology of analysis and virtual recomposition: the case of Retrosi (Amatrice, Italy). In Amoruso G. (a cura di). Putting tradition into practice: heritage, place and design. Milano: Springer International, pp. 75-83.

Canciani M., et al. (2019). Cartografia aggiornata del centro storico di Tivoli: contributi al GIS del territorio del Comune. In: (a cura di): Martines R., Pallottino E., TIVOLI, UN LABORATORIO URBANO leri, oggi, domani. Roma: Edizioni Roma TrE-Press, pp. 97-126.

Chen J., Clarke K. C. (2016). Rapid 3D modeling Using photogrammetry applied to Google Earth. In Indoor 3D Mapping, Pittsburgh, Pennsylvania: AutoCarto.

Cozzetto F. (200I). Città di Calabria e hinterland nell'età moderna: demografia e strutture amministrative e sociali. Rubbettino Editore.

D'Avino, V. ( 848$)$. Cenni storici sulle chiese arcivescovili, vescovili, e prelatizie (nulluis) del Regno delle Due Sicilie raccolti, annotati, scritti per l'ab.Vincenzo D'Avino, dalle stampe di Ranucci.

De Luca R., Gigliotti V. et al. (2016). Spectroscopic, microchemical and petrographic analyses of plasters from ancient buildings in Lamezia Terme (Calabria, Southern Italy). In Spectrochimica Acta Part A: Molecular and Biomolecular Spectroscopy, I 53, I 84193.

Francini M., Colucci M., Palermo A., Viapiana M.F. (2019). I centri storici minori. Strategie di rigenerazione funzionale. Milano: FrancoAngeli.

Guidoboni E. (20 I7). II valore della memoria. Terremoti e Ricostruzioni in Italia nel lungo periodo. In Quellen und Forschungen aus italienischen Archiven und Bibliotheken, vol. 96/2016.

Laganà F. (2020). Conoscere per tutelare e valorizzare il patrimonio architettonico: il centro storico di Sambiase e Palazzo Cerra, analisi, rilievo e conservazione. Tesi di laurea magistrale in Architettura-Restauro, relatore M. Canciani; correlatori P. Brunori, G. Spadafora. Dipartimento di Architettura di Roma Tre.

Maestri D., Spadafora G. (2016). Ambiente e architetture di San Giovanni in Fiore. Roma: Gangemi Editore.

Mazza F. (200 I). Lamezia Terme: storia, cultura, economia (Vol. I I). Soveria Mannelli: Rubbettino Editore.

Paletta M.G. (2007) Indagini sul patrimonio in terra nel lametino. Tesi di laurea. Relatore prof. S. Mecca, correlatori prof. C. Cuomo, arch. L. Dipasquale. Università degli Studi di Firenze. 
Panarello M. (2005). Architettura residenziale del Sei e Settecento in Calabria, Note per una catalogazione regionale. Reggio Calabria: liriti Editore.

Panarello M. (2009). Architettura e decorazione nelle dimore nobiliari calabresi del '600 e '700, in Atlante Tematico del Barocco in Italia, II sistema delle residenze nobiliari - Italia meridionale. Roma: De Luca editori d'Arte.

Proto N., Cicione F. (2005). L'edilizia di tradizione rurale nella conformazione delle aree urbane lametine. In B. Biondi (Ed.) Ist international research seminar on architectural heritage and sustainable development of small and medium cities in south Mediterranean regions: results and strategies of research and cooperation, pp. 495-509. Pisa: Edizioni ETS.

Remondino F., El-Hakim S. (2006). Image-based 3D modelling: a review. In The Photogrammetric Record, Vol.2I (I I 5), pp. 269-291.

Authors

Marco Canciani, Università degli Studi RomaTre, marco.canciani@uniroma3.it

Giovanna Spadafora, Università degli Studi RomaTre, giovanna.spadafora@uniroma3.it

Paola Brunori, Università degli Studi Roma Tre, paola.brunori6@virgilio.it

Francesca Laganà, Università degli Studi RomaTre, lagana.fa@gmail.com

To cite this chapter. Canciani Marco, Spadafora Giovanna, Brunori Paola, Laganà Francesca (202I). II lessico formale dell'architettura storica: il caso del centro storico di Sambiase/The formal lexicon of historic architecture: the case of the historic center of Sambiase. In Arena A., Arena M. Mediati D., Raffa P. (a cura di). Connettere. Un disegno per annodare e tessere. Linguaggi Distanze Tecnologie. Atti del $42^{\circ}$ Convegno Internazionale dei Docenti delle Discipline della Rappresentazione/Connecting. Drawing for weaving relationship. Languages Distances Technologies. Proceedings of the $42^{t}$ International Conference of Representation Disciplines Teachers. Milano: FrancoAngeli, pp. 258-306. 